\title{
What is the Risk of Having Offspring with Cleft Lip/Palate in Pre-Maternal Obese/Overweight Women When Compared to Pre-Maternal Normal Weight Women? A Systematic Review and Meta-Analysis
}

\author{
Omoroghogho Maria Izedonmwen ${ }^{1}$, Claudia Cunningham ${ }^{1}$, Tatiana V. Macfarlane ${ }^{1}$ \\ ${ }^{1}$ School of Medicine and Dentistry, University of Aberdeen, Aberdeen, United Kingdom.
}

\author{
Corresponding Author: \\ Tatiana V. Macfarlane \\ University of Aberdeen Dental School \\ Cornhill Road, Foresterhill, Aberdeen, AB25 2ZR \\ United Kingdom \\ Phone: (+44) (0)1224 551585 \\ E-mail: Tatiana.Macfarlane@abdn.ac.uk
}

\begin{abstract}
Objectives: The purpose of the study was to identify the risk of orofacial cleft in the offspring of women with pre-maternal obesity/overweight when compared with pre-maternal normal weight women.

Material and Methods: MEDLINE and EMBASE were searched from 1980 to July 2014 for cohort, case control and cross sectional studies. BMI were categorized according to WHO recommendation: normal weight (BMI 18.5 - 24.9), overweight (BMI 25 - 29.9) and obese (BMI $\geq 30$ ).

Results: Six studies were identified; three case control studies which were used for the meta-analysis and two cross sectional studies and one cohort study. Compared with women of recommended BMI, obese women were at increased odds of pregnancy affected by CLP $(\mathrm{OR}=1.16 ; 95 \%$ CI $1,1.34)$ and $\mathrm{CP}(\mathrm{OR}=1.14 ; 95 \%$ CI $0.95,1.37)$. Overweight women were also at increased odds of pregnancy affected by CLP $(\mathrm{OR}=1.06 ; 95 \% \mathrm{CI} 0.93,1.21)$ but not CP $(\mathrm{OR}=0.89 ; 95 \% \mathrm{CI} 0.75,1.06)$. The results of the risk ratios reported in the cross sectional and cohort studies were similar to the results of the meta-analysis. Conclusions: The results of this study reveal that there is an increased risk of having offspring with orofacial cleft in obese/ overweight women. The reason for this association is not known. Although, the risk is small, it is important because of the increasing incidence of obesity.
\end{abstract}

Keywords: cleft palate; nonsyndromic cleft lip/palate; orofacial cleft 1.

Accepted for publication: 29 December 2014

To cite this article:

Izedonmwen OM, Cunningham C, Macfarlane TV. What is the Risk of Having Offspring with Cleft Lip/Palate in PreMaternal Obese/Overweight Women When Compared to Pre-Maternal Normal Weight Women? A Systematic Review and Meta-Analysis.

J Oral Maxillofac Res 2015;6(1):e1

URL: http://www.ejomr.org/JOMR/archives/2015/1/e1/v6n1e1.pdf

doi: $10.5037 /$ jomr.2015.6101 


\section{INTRODUCTION}

Obesity is regarded as a medical condition characterized by excessive accumulation of body fat to the extent that it has an adverse effect on health [1]. Body Mass Index (BMI), waist-hip ratio and body fat percentage are different measures used to identify obesity [2]. Obesity can be defined as a BMI of greater than or equal to 30 [3]. An index of less than 18.5 can be considered underweight, normal weight is 18.5 to 24.9 and overweight is a BMI of 25 to 29.9. Obesity predisposes an individual to various types of diseases such as osteoarthritis, high blood pressure, diabetes, heart diseases and some cancers [4]. According to The World Health Organization (WHO), it is estimated globally that about 2.8 million people die each year as a result of being overweight or obese. About 35.8 million (2.3\%) of global Disability Adjusted Life Years (DALYs) are caused by overweight or obesity [ $\underline{5}$.

Since the 1980 s, the prevalence of obesity has almost doubled [6]. The World Health Organization reported that in $2008,35 \%$ of adults aged 20 years and above were overweight and $12 \%$ were obese. Ten per cent of the obese populations were females, and $14 \%$ were males [7]. The aetiology of obesity is multifactorial; it is influenced by genetic and environmental risk factors []]. Genetic data based on twins, adoption and family history revealed that about $50 \%$ of the inter-individual variance in BMI is due to the genetic makeup of the individual [9]. The environmental influence of lack of exercise and high-calorie dense food intake also increases the risk of getting obese [10].

There has been an increase in obesity among women of childbearing age. In the United States of America, it was reported that pre-maternal obesity increased from $17.6 \%$ in 2003 to $20.5 \%$ in 2009 [11]. In the United Kingdom, between 1990 and 2004, there was a rise in pre-maternal obesity from $9.9 \%$ to $16 \%$ [12]. Swaziland has the highest rate of maternal obesity in Africa [13]. In 2012, it was reported that $27 \%$ of pregnant women were obese while $23 \%$ were overweight [13]. Maternal obesity has been shown to be strongly associated with obstetric complications such as cesarean delivery, early neonatal death, large babies, preeclampsia, as well as congenital malformations in the child [14].

Orofacial is the most common craniofacial congenital abnormality [15]. It can occur either as a single entity of cleft palate (CP) or cleft lip (CL). It can also occur in combination as $\mathrm{CL}+\mathrm{CP}$. Approximately $50 \%$ of babies with $\mathrm{CL}$ will also have $\mathrm{CP}$ [16]
The combined entity of CL + CP and CL only are thought to be variant of the same defect and $\mathrm{CL}+$ $\mathrm{CP}$ being a more severe form of CL only [17]. The term cleft lip with or without palate (CLP) is used in describing cases of CL only or those that present with both CP + CL. Thus, orofacial clefts are broadly classified into two categories, CP and CLP. Cleft lip can be bilateral or unilateral and is mainly found on the left side [18].

Orofacial clefts are embryonic defect that are caused by the failure of the necessary embryonic processes to unite completely. Formation of the lip and palate occur at different period. The lip forms at about the $6^{\text {th }}$ week of embryonic life and total palate closure occurs at the $12^{\text {th }}$ week [19]. All structures involved in the formation of lip and palate usually migrate and meet at the middle. When these parts fail to unite, it results in a gap. When the gap occurs on the lip, it is referred to as CL and if it is on the palate it is called CP [19].

About 1 in 700 live births globally are affected with CLP [20], and 6.4 in $10000 \mathrm{CP}$ alone [21]. The incidence of orofacial cleft varies according to ethnicity, geographical location and socioeconomic status [22-24]. The Asian and Native American populations have the highest birth incidence rate of 1 in 500 births of orofacial cleft [25]. The incidence is lowest for African American populations, were it is around 0.3 per 1,000 live births [26]. Caucasians population risks have been found to be around, 1 per 1000 whilst Japanese populations risk is around 2 per 1,000 births [23].

The birth incidence between 1998 and 2011 revealed that Northern Finland had the highest CP incidence rate when compared with their European counterparts [27]. There has been a reported rise in the incidence in Denmark from 1.45 in 1000 in 1942 to 1.89 in 1000 in 1981 [28]. Whilst in The United Kingdom, the Scottish Needs Assessment Programme report suggested there was a decrease of orofacial cleft from 1 in 930 to 1 in 1054 from 1990 to 1995 [29]. However, the trend globally from available data has not shown any reduction in incidence rate [29].

The aetiology of orofacial cleft is poorly understood but regarded as multifactorial. Both genetic, as well as environmental factors have been implicated [30]. In siblings, if the first-born child has got CLP the chances of the second born having CLP is 3\% to $4 \%$. If two children within a family have it, the probability of the third child being born with CLP is 9\% [29]. The environmental risk factors include low folic acid levels in the mother, smoking and alcohol intake during pregnancy, poor diet, some medicinal drugs and viral infections [23]. 
It is thought that the aetiology of CLP is different from $\mathrm{CP}$ alone because they both have different risk factors [31]. CLP occurs twice as much in males than in females while the reverse is the case with $\mathrm{CP}$, which occurs twice as much in females compared to males [25].

Orofacial cleft causes problems for both the child and parent. It causes feeding, hearing, speech difficulty for the child and the child is more prone to infections [31]. It causes psychosocial problems for the parent usually because of the distorted physical appearance of the child [31].

Maternal obesity has been associated with a range of congenital malformations such as spina bifida, neural tube defects, cardiovascular anomalies as well as orofacial cleft $[\underline{32}, \underline{33}]$.

The reason for the relationship between a range of birth defects and maternal obesity is unknown [32]. There is evidence to show that birth defect occur more in diabetic women when compare with women without diabetes [34]. It has been suggested that it maybe the same mechanism that is responsible for the association between diabetes and congenital malformation that is also responsible for the association between obesity and congenital malformations [35]. Studies have provided evidence that alterations in glycemic control maybe responsible for the increased risk of a spectrum of structural birth defects seen in women that have diabetes $[\underline{36}, \underline{37}]$. Alteration in glycemic control is also associated with obesity [38]. Another explanation for the association between maternal obesity and congenital malformation is that maternal obesity is associated with nutritional deficiencies especially reduced folate levels [39]. There is evidence to show that low folate levels in pregnant women increases the risk of orofacial clefts in their offspring [40-43].

Different epidemiological studies have been done to investigate the relationship between obesity and orofacial clefts. They found an increase in the risk of having offspring with orofacial in obese women [44-46]. Some studies have reported close to null but increased risk as well $[32,47]$. However, the definition of obesity, overweight and even normal weight varied amongst the studies. So to compare the results of these studies would not be appropriate.

A systematic review has been conducted but was done to determine the association between obesity and congenital malformations in general [48]. Another systematic review was conducted to determine the effect of a range of environmental factors, which included obesity as well on cleft lip and palate [49]. In both reviews, studies that did not classify obesity according to WHO recommendation were included.
The aim of this systematic review was to determine if there is an increased risk of having offspring with cleft palate and cleft lip/palate in pre-maternal obese/ overweight women when compared with pre-maternal normal weight women.

\section{MATERIAL AND METHODS}

The protocol of the review was registered with the international prospective register of systematic reviews PROSPERO (www.crd.york.ac.uk/PROSPERO/) with registration number CRD42014009973. We followed PRISMA guidelines (www.prisma-statement. org) and MOOSE guideline for reporting [무]

\section{Types of publications}

To be included in this systematic review, the studies had to be observational studies of cohort, case control or cross sectional design. Case series, case report and randomized control trials were excluded because they were not considered suitable in answering the research question. Study publication was restricted to 1980 to July 2014. This date was chosen because obesity has been on a significant rise since about 1980 [1]. Only full text published articles were included.

\section{Inclusion criteria}

Participants of studies had to be mothers with a known pre-maternal BMI that was classified into obese (BMI $\geq 30$ ), overweight (BMI 25 - 29.9) or normal weight/reference weight (BMI 18.5 to $>24.9$ ). It has been reported that there is an increased risk of non-isolated orofacial cleft in obese and overweight women when compared with isolated cases [44]. Also, CP and CLP are thought to have different risk factors and should be separately analyzed [23]. So it was decided that orofacial cleft should be to subdivided for this review into CP and CLP and also into isolated and non-isolated case.

For a study to be eligible the outcome of orofacial clefts should be sub-divided into CP or CLP. The proportion of these outcomes has to be reported in the obese, overweight and normal weight groups. If the effect sizes of odds ratio (OR) or risk/rate ratio (RR) are reported, the study was also considered.

\section{Exclusion criteria}

Participants of studies were excluded if the mother's pre-maternal BMI was not reported and if their BMI was not classified according to WHO recommendation. 
Studies were excluded if only the outcome of orofacial cleft was reported in general and none of the outcome of the subgroup (CP or CLP) of orofacial cleft was reported. Also excluded were studies that reported just congenital malformations in general and syndromic orofacial clefts.

\section{Search strategy}

A comprehensive electronic literature search of MEDLINE (from 1946 till week 1 July 2014) was done. The search result was then limited to 1980. EMBASE was also searched (from 1980 till 2014 week 27). The search strategy was internally peer-reviewed. It was done using Medical Subject Heading (MeSH) and text words of terms such as: "OBESITY", "OVERWEIGHT", "PREGNANT WOMEN", "MOTHERS", "GRAVID", "EXPECTANT", "MATERNAL", "CHILD”, "INFANT", "BABIES", “OFFSPRING", "CLEFT LIP", "CLEFT PALATE", "CLEFT LIP PALATE", "OROFACIAL CLEFT", "CHEILOSCHISIS", "HARE LIP", "PALATOSCHISTIS", "CONGENITAL ABNORMALITIES" and "MALFORMATIONS". Wildcards and truncations were used, and words were combined with Boolean operators such as "OR" and "AND" when appropriate. The search strategy for MEDLINE is shown in Appendix 1. The same search strategy was modified for EMBASE.

Google scholar search engine was used using "MATERNAL OBESITY" and "CONGENITAL MALFORMATIONS" and "MATERNAL OBESITY" and "CLEFT LIP + PALATE". This resulted in a lot of studies, but only the first 40 articles were screened. A manual search of journals was not done because of time constraints. Furthermore, a search of the references of relevant articles was done in order to identify more studies. The search was restricted to articles published in English language due to time constraints. Animal studies were excluded. There were no study restrictions when the search was done because the reference lists of all types of studies were to be screened to identify any important article. The last search was conducted on $4^{\text {th }}$ July 2014.

\section{Study selection}

The title and abstracts of all the papers were read, and all potentially relevant articles were identified.

The full texts of the potentially relevant articles were read by one reviewer and checked independently by the supervisors. The articles that did not meet the inclusion criteria were excluded. Any discrepancies were resolved by consensus.

\section{Data extraction}

Data from the selected relevant studies were extracted using a Data extraction form, which was designed by the authors during the protocol stage of this review. This was done by one reviewer and checked by the supervisors. Information was gathered on: Author and year of publication, country of study, ethnicity of the participants, study period, study size, number of control and cases of CP and CLP, sources of case and control selection, source of weight and height measurement, number in exposed and unexposed group, odds ratio or adjusted odds ratio, risk ratio or adjusted risk ratio and $95 \%$ confidence interval.

\section{Quality assessment}

The quality of the studies was assessed using the Critical Appraisal Skills Programme (CASP) methodology checklist for case control studies [51] and cohort studies [52]. The quality assessment was done by one reviewer and was checked by the supervisors. The CASP checklist consists of three aim sections. The first section is used to assess the validity of the studies; that is if the studies were conducted appropriately to answer the research question. It also scrutinizes the method of recruiting cases and controls. This is relevant in order to know if there was selection bias. The second section is used to assess the results of the study and how precise they are and also how confounding and risk factors were addressed. This is important because confounding variables and risk factors mask the true results of the study if they are not controlled for. The third addresses the issue of generalizability and relevance of the study. There are a total of eleven questions and hints on how to answer the questions. Three answers are available to choose from; "Yes", "Can't tell" or "No" but not for questions 7 and 8 in which the results are required.

\section{Statistical analysis}

Using raw data, the percentages of cases in the overweight group and the obese group women were calculated and also that of the normal weight group. Meta-analysis was performed separately for obese and overweight and risk of CP or CLP using Review Manager software version 5.3 [드]. The OR and 95\% Confidence Interval $(95 \% \mathrm{CI})$ was calculated with a fixed effect model. A P-value of $<0.05$ was considered statistically significant. Forest plots were used to illustrate the results. Chi-squared test and $\mathrm{I}^{2}$ statistics were used to evaluate heterogeneity (amount of between study variation in relation to the total 
variation). An $\mathrm{I}^{2}$ statistics of $>50 \%$ was considered not significant for the test of heterogeneity. Funnel plots were used to examine the risk of publication bias.

\section{RESULTS}

\section{Search results}

Figure 1 shows a flow diagram of the search result and study selection. There were 106 and 163 articles found in MEDLINE and EMBASE respectively. Google scholar search engine was also searched but no further relevant articles were identified. Of the total 269 articles found, 29 (10.8\%) were considered to be potentially relevant by reading their titles and abstract. Reviews $(n=2)$, duplicates $(n=13)$ and one potentially relevant article with title "Maternal obesity increases risk of congenital anomalies: a populationbased study" by Mutsaerts et al. [54] were removed. The study by Mutsaerts [54], was presented at the $29^{\text {th }}$ annual meeting of the European Society of Human Reproduction and Embryology, London in July 2013, but only the abstract was available, and there was no full text of the article therefore it could not be considered.
At this point, thirteen articles were left of which seven had to be discarded for not meeting the inclusion criteria. Tables 1 - 3 summarize the description of the excluded case control, cohort and cross sectional studies respectively.

The main reason for not including potentially relevant articles for this systematic review was due to the discrepancies in classification of weight. Most studies did not use the WHO recommended method of classifying BMI to define obesity, overweight or normal weight $[\underline{44}, \underline{45}, \underline{47}, \underline{68}]$. For example, in Cedegren and Kallen's [44] study, normal weight was classified as a BMI of 19.8 to 26 instead of WHO recommendation of 18.5 to 24.9. Shaw et al. [47] compared obesity, which they regarded as a BMI of $>29$ with the reference weight which was BMI $<29$. The reference weight thus included overweight, normal weight and underweight. Oddy et al. [55] referred to normal weight as a BMI of between 20 to $<25$, which is not according to WHO recommendation and reported the outcome of orofacial cleft in general. In one of the articles, weight was classified according to tertiles and also they did not report the outcome of cleft but only reported congenital malformations [56]. Villamor et al. [57], classified weight according to change in weight

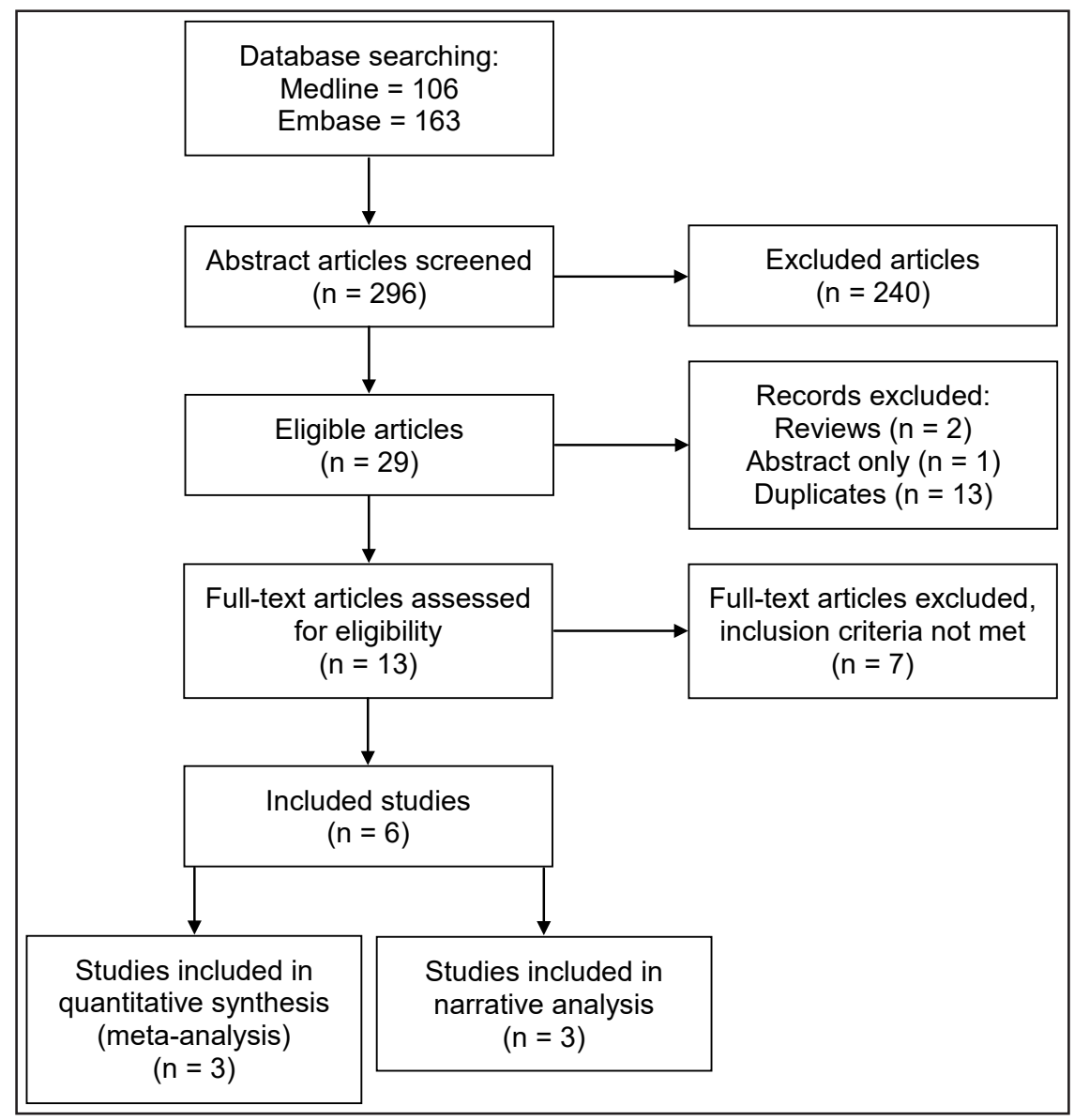

Figure 1. Flow diagram of study selection process (adapted from PRISMA statement). 
and so it was excluded.

In one of the cross sectionals identified; they did categorize BMI according to WHO recommendation, but the outcome of orofacial cleft in general was reported. They did not divide orofacial cleft into $\mathrm{CP}$ or CLP thus the study was excluded [33].

Therefore, a total of six studies were deemed to be eligible for this systematic review. Three of which were case controls that were used for the meta analysis $[\underline{32}, \underline{46}, \underline{58}]$. Two cross sectional studies $[\underline{59}, \underline{60}]$ and one cohort study [타]

\section{Studies included in meta-analysis}

Table 4 shows the characteristics of the included studies for this review and Table 5 show the description of the cases and controls for the case control studies. The case control studies were published between 2003 and 2010 but covered a study period from 1992 to 2005. They were all conducted in the USA. Two of the studies primary aims were to determine the association between pre-maternal obesity/overweight

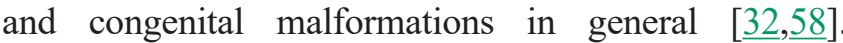

Table 1. Description of excluded case control studies

\begin{tabular}{|c|c|c|c|c|c|c|c|c|c|}
\hline $\begin{array}{c}\text { First } \\
\text { author }\end{array}$ & $\begin{array}{c}\text { Year of } \\
\text { publication }\end{array}$ & Location & $\begin{array}{l}\text { Study } \\
\text { period }\end{array}$ & $\begin{array}{l}\text { Recruitment of } \\
\text { cases }\end{array}$ & $\begin{array}{l}\text { Recruitment of } \\
\text { controls }\end{array}$ & $\begin{array}{l}\text { Weight/height } \\
\text { measurement }\end{array}$ & $\begin{array}{c}\text { BMI } \\
\text { classification }\end{array}$ & Adjusted for & $\begin{array}{c}\text { Outcomes } \\
\text { reported }\end{array}$ \\
\hline $\begin{array}{c}\text { Shaw et al. } \\
{[\underline{47]}}\end{array}$ & 2000 & $\begin{array}{c}\text { California, } \\
\text { USA }\end{array}$ & $\begin{array}{c}\text { Jan } 1987 \\
\text { to } \\
\text { Dec } 1989\end{array}$ & $\begin{array}{c}\text { Medical records of } \\
\text { California Counties } \\
\text { (live births and fetal } \\
\text { deaths) }\end{array}$ & \begin{tabular}{|} 
Randomly selected \\
from California \\
Counties \\
(live births)
\end{tabular} & $\begin{array}{c}\text { Retrospectively } \\
\text { self reported by } \\
\text { mother }\end{array}$ & $\begin{array}{c}\mathrm{NW}^{\mathrm{a}} \leq 29 \\
\text { Obese }^{\mathrm{b}}>29\end{array}$ & $\begin{array}{c}\text { Stratified by } \\
\text { maternal race/ } \\
\text { ethnic group }\end{array}$ & $\begin{array}{l}\text { CLP } \\
\text { CP }\end{array}$ \\
\hline $\begin{array}{c}\text { Oddy et al. } \\
{[\underline{55}]}\end{array}$ & 2009 & $\begin{array}{c}\text { Western } \\
\text { Australia }\end{array}$ & $\begin{array}{c}\text { Sep } 1997 \\
\text { to } \\
\text { Mar 2000 }\end{array}$ & $\begin{array}{c}\text { Western Australian } \\
\text { Birth Defects } \\
\text { Registry (live births, } \\
\text { stillbirths and } \\
\text { terminations) }\end{array}$ & $\begin{array}{l}\text { Random sample } \\
\text { from Western } \\
\text { Australia } \\
\text { (life births) }\end{array}$ & $\begin{array}{l}\text { Retrospectively } \\
\text { self reported }\end{array}$ & $\mid \begin{array}{c}\mathrm{NW}^{\mathrm{a}} 20 \text { to }<25 \\
\mathrm{OW}^{\mathrm{c}} 25 \text { to }<30 \\
\text { Obese } 30+\end{array}$ & $\begin{array}{c}\text { Marital status, } \\
\text { maternal age, } \\
\text { maternal } \\
\text { education, folic } \\
\text { acid intake }\end{array}$ & $\begin{array}{c}\text { Orofacial } \\
\text { cleft }^{\mathrm{d}}\end{array}$ \\
\hline
\end{tabular}

${ }^{a}$ Excluded because NW is not according to WHO classification.

${ }^{b}$ Excluded because obese is not according to WHO classification.

cExcluded because OW is not according to WHO classification.

dExcluded because orofacial cleft was not sub-divided.

$\mathrm{NW}=$ normal weight (reference weight); $\mathrm{OW}=$ overweight; $\mathrm{CP}=$ cleft palate; CLP $=$ cleft lip with or without palate; orofacial cleft $=\mathrm{CP}+\mathrm{CLP} ; \mathrm{BMI}=$ body mass index

Table 2. Description of excluded cohort studies

\begin{tabular}{|c|c|c|c|c|c|c|c|c|}
\hline First author & $\begin{array}{c}\text { Year of } \\
\text { publication }\end{array}$ & Location & $\begin{array}{l}\text { Study } \\
\text { period }\end{array}$ & Study population & $\begin{array}{l}\text { Weight/height } \\
\text { measurement }\end{array}$ & $\begin{array}{c}\text { BMI } \\
\text { classification }\end{array}$ & Adjusted for & $\begin{array}{l}\text { Outcomes } \\
\text { reported }\end{array}$ \\
\hline $\begin{array}{c}\text { Moore et al. } \\
{[\underline{45]}}\end{array}$ & 2000 & $\begin{array}{l}\text { Boston, } \\
\text { USA }\end{array}$ & $\begin{array}{c}\text { Oct } 1984 \\
\text { to } \\
\text { Jun } 1987\end{array}$ & $\begin{array}{c}\text { Women who had } \\
\text { MSAFP screening } \\
\text { and were receiving } \\
\text { prenatal care in } \\
\text { Boston }\end{array}$ & $\begin{array}{l}\text { Retrospectively } \\
\text { self reported by } \\
\text { mother }\end{array}$ & $\begin{array}{c}\mathrm{UW}<25 \\
\mathrm{NW}^{\mathrm{a}} 25 \text { to }<28 \\
\text { Obese }^{\mathrm{b}} \geq 28\end{array}$ & $\begin{array}{c}\text { Maternal age, education, } \\
\text { first trimester cigarette use, } \\
\text { alcohol intake, folic acid } \\
\text { and retinol intake during } \\
\text { pregnancy }\end{array}$ & Orofacial cleft \\
\hline $\begin{array}{c}\text { Garcia- } \\
\text { Patterson et al. } \\
{[\underline{56}]}\end{array}$ & 2004 & $\begin{array}{c}\text { Barcelona, } \\
\text { Spain }\end{array}$ & $\begin{array}{c}\text { Jan } 1986 \\
\text { to } \\
\text { Jul } 2002\end{array}$ & \begin{tabular}{|} 
Women with \\
gestational \\
diabetes in the \\
Hospitals of Holy \\
Cross and St Paul's
\end{tabular} & Did not say & $\begin{array}{c}1^{\text {st }} \text { tertile } \\
(15.43,21.91) \\
2^{\text {nd }} \text { tertile }^{\mathrm{a}} \\
(21.92,24.77) \\
3^{\text {rd }} \text { tertile } \\
(24.78,47.07)\end{array}$ & $\begin{array}{l}\text { Maternal age, smoking in } \\
\text { first trimester }\end{array}$ & $\begin{array}{c}\text { Congenital } \\
\text { malformations }\end{array}$ \\
\hline $\begin{array}{c}\text { Villamor et al. } \\
{[\underline{57}]}\end{array}$ & 2008 & Sweden & $\begin{array}{l}1992 \\
\text { to } \\
2004\end{array}$ & $\begin{array}{c}\text { Women with } \\
\text { births recorded on } \\
\text { Swedish Medical } \\
\text { Birth Registry }\end{array}$ & $\begin{array}{c}\text { At first } \\
\text { antenatal visit }\end{array}$ & Change in $\mathrm{BMI}^{\mathrm{c}}$ & $\begin{array}{l}\text { Mother's country of origin, } \\
\text { maternal age, paternal } \\
\text { age, mothers education, } \\
\text { smoking, complications at } \\
\text { pregnancy }\end{array}$ & $\begin{array}{l}\text { CL } \\
\text { CP } \\
\text { CLP }\end{array}$ \\
\hline
\end{tabular}

${ }^{a}$ Excluded because NW is not according to WHO classification.

${ }^{b}$ Excluded because obese is not according to WHO classification.

"Excluded because reference weight was "change in BMI".

${ }^{\mathrm{d}}$ Excluded because congenital malformation included all forms of malformation and the did not report the outcomes of individual malformation.

${ }^{\mathrm{e} E x c l u d e d ~ b e c a u s e ~ o r o f a c i a l ~ c l e f t ~ w a s ~ n o t ~ s u b-d i v i d e d . ~}$

MSAFP = maternal serum $\alpha$-fetoprotein; $\mathrm{NW}=$ normal weight (reference weight); $\mathrm{UW}=$ underweight; $\mathrm{CL}=\mathrm{cleft}$ lip; $\mathrm{CP}=\mathrm{cleft}$ palate; $\mathrm{CLP}=$ cleft lip with or without palate; orofacial cleft $=\mathrm{CP}+\mathrm{CLP} ; \mathrm{BMI}=$ body mass index . 
Table 3. Description of excluded cross sectional studies

\begin{tabular}{|c|c|c|c|c|c|c|c|}
\hline Authors & $\begin{array}{c}\text { Year of } \\
\text { publication }\end{array}$ & Location & Study period & $\begin{array}{l}\text { Weight/height } \\
\text { measurement }\end{array}$ & $\begin{array}{c}\text { BMI } \\
\text { classification }\end{array}$ & Adjusted for & $\begin{array}{c}\text { Outcomes } \\
\text { reported }\end{array}$ \\
\hline $\begin{array}{c}\text { Blomberg and } \\
\text { Kallen [33] }\end{array}$ & 2010 & Sweden & $\begin{array}{c}\text { Jan } 1995 \\
\text { to } \\
\text { Dec } 2007\end{array}$ & $\begin{array}{c}\text { First antenatal clinic } \\
\text { by mid wife }\end{array}$ & $\begin{array}{c}\mathrm{UW}<18.5 \\
\text { NW } 18.5 \text { to } 24.9 \\
\text { OW } 25 \text { to } 29.9 \\
\text { Obese } \geq 30\end{array}$ & $\begin{array}{l}\text { Maternal age, parity, } \\
\text { smoking, year of birth }\end{array}$ & Orofacial cleft ${ }^{\mathrm{d}}$ \\
\hline $\begin{array}{c}\text { Cedegren and } \\
\text { Kallen [44] }\end{array}$ & 2005 & Sweden & $\begin{array}{c}\text { Jan } 1992 \\
\text { to } \\
\text { Dec } 2001\end{array}$ & First antenatal visit & $\begin{array}{c}\mathrm{UW}<19.8 \\
\mathrm{NW}^{\mathrm{a}} 19.8 \text { to } 26 \\
\mathrm{OW}^{\mathrm{b}} 26.1 \text { to } 29 \\
\text { Obese }^{\mathrm{c}}>29\end{array}$ & $\begin{array}{c}\text { Year of birth, maternal } \\
\text { age, parity, maternal } \\
\text { smoking }\end{array}$ & $\begin{array}{l}\text { CL } \\
\text { CP } \\
\text { CLP }\end{array}$ \\
\hline
\end{tabular}

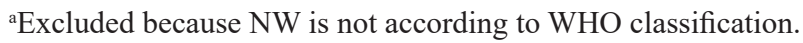

${ }^{b}$ Excluded because OW is not according to WHO classification.

'Excluded because obese is not according to WHO classification.

${ }^{d}$ Excluded because orofacial cleft was not sub-divided.

$\mathrm{NW}=$ normal weight (reference weight); $\mathrm{OW}=$ overweight; $\mathrm{UW}=$ underweight; $\mathrm{CL}=$ cleft lip; $\mathrm{CP}=$ cleft palate; CLP = cleft lip with or without palate; orofacial cleft $=\mathrm{CP}+\mathrm{CLP}$.

Table 4. Description of included studies

\begin{tabular}{|c|c|c|c|c|c|c|c|c|}
\hline First author & $\begin{array}{c}\text { Year of } \\
\text { publication }\end{array}$ & Location & $\begin{array}{l}\text { Type of } \\
\text { study }\end{array}$ & $\begin{array}{l}\text { Study } \\
\text { period }\end{array}$ & $\begin{array}{l}\text { Weight/height } \\
\text { measurement }\end{array}$ & BMI classification & Adjusted for & $\begin{array}{l}\text { Outcomes } \\
\text { reported }\end{array}$ \\
\hline $\begin{array}{c}\text { Waller et al. } \\
{[\underline{32}]}\end{array}$ & 2007 & USA & $\begin{array}{l}\text { Case } \\
\text { control }\end{array}$ & $\begin{array}{c}\text { Oct } 1,1997 \\
\text { to } \\
\text { Dec } 31 \\
2002\end{array}$ & $\begin{array}{l}\text { Retrospectively } \\
\text { self-reported by } \\
\text { the mother }\end{array}$ & $\begin{array}{c}\mathrm{UW}<18.5 \\
\mathrm{NW} \geq 18.5 \text { to }<25 \\
\mathrm{OW} \geq 25 \text { to }<30 \\
\text { Obese } \geq 30\end{array}$ & $\begin{array}{c}\text { Maternal race/ } \\
\text { ethnicity, maternal age, } \\
\text { maternal educational } \\
\text { level, parity, maternal } \\
\text { smoking, folic acid } \\
\text { intake }\end{array}$ & $\begin{array}{l}\text { CP } \\
\text { CLP }\end{array}$ \\
\hline $\begin{array}{c}\text { Stott-Miller } \\
\text { et al. } \\
{[\underline{46}]}\end{array}$ & 2010 & $\begin{array}{l}\text { Washington, } \\
\text { USA }\end{array}$ & $\begin{array}{l}\text { Case } \\
\text { control }\end{array}$ & $\begin{array}{l}1987 \\
\text { to } \\
2005\end{array}$ & $\begin{array}{l}\text { Birth certificate } \\
\text { and drivers } \\
\text { license records }\end{array}$ & $\begin{array}{c}\mathrm{UW}<18.5 \\
\mathrm{NW} \geq 18.5 \text { to }<25 \\
\mathrm{OW} \geq 25 \text { to }<30 \\
\text { Obese } \geq 30\end{array}$ & $\begin{array}{c}\text { Maternal education, } \\
\text { maternal age, maternal } \\
\text { smoking, maternal race, } \\
\text { frequency matched for } \\
\text { year of birth }\end{array}$ & $\begin{array}{l}\mathrm{CP} \\
\mathrm{CLP}\end{array}$ \\
\hline $\begin{array}{c}\text { Watkins et al. } \\
{[\underline{58}]}\end{array}$ & 2003 & $\begin{array}{l}\text { Atlanta, } \\
\text { USA }\end{array}$ & $\begin{array}{l}\text { Case } \\
\text { control }\end{array}$ & $\begin{array}{c}\text { Jan } 1992 \\
\text { to } \\
\text { Aug } 1997\end{array}$ & $\begin{array}{l}\text { Retrospectively } \\
\text { self-reported by } \\
\text { the mother }\end{array}$ & $\begin{array}{c}\mathrm{UW}<18.5 \\
\text { NW } 18.5 \text { to } 24.9 \\
\text { OW } 25 \text { to } 29.9 \\
\text { Obese } \geq 30\end{array}$ & $\begin{array}{c}\text { Maternal age, } \\
\text { education, alcohol } \\
\text { use, smoking, peri } \\
\text { conceptional vitamin } \\
\text { use, race }\end{array}$ & $\begin{array}{l}\mathrm{CL} \\
\mathrm{CP} \\
\mathrm{CLP}\end{array}$ \\
\hline $\begin{array}{c}\text { Block et al. } \\
{[\underline{59}]}\end{array}$ & 2013 & $\begin{array}{l}\text { Florida, } \\
\text { USA }\end{array}$ & $\begin{array}{c}\text { Cross } \\
\text { sectional }\end{array}$ & $\begin{array}{c}\text { Mar } 2004 \\
\text { to } \\
\text { Dec } 2009\end{array}$ & $\begin{array}{l}\text { From Birth } \\
\text { certificate }\end{array}$ & $\begin{array}{c}\text { UW }<18.5 \\
\text { NW } 18.5 \text { to } 24.9 \\
\text { OW } 25.0 \text { to } 29.9 \\
\text { Obese } \geq 30\end{array}$ & $\begin{array}{c}\text { Maternal race/ethnicity, } \\
\text { maternal education, } \\
\text { maternal smoking, } \\
\text { maternal marital status, } \\
\text { maternal nativity, } \\
\text { maternal age }\end{array}$ & $\begin{array}{l}\text { CP } \\
\text { CLP }\end{array}$ \\
\hline $\begin{array}{c}\text { Marengo et al. } \\
{[\underline{60}]}\end{array}$ & 2013 & $\begin{array}{l}\text { Texas, } \\
\text { USA }\end{array}$ & $\begin{array}{c}\text { Cross } \\
\text { sectional }\end{array}$ & $\begin{array}{l}2005 \\
\text { to } \\
2008\end{array}$ & $\begin{array}{l}\text { Birth/death } \\
\text { certificates }\end{array}$ & $\begin{array}{c}\mathrm{UW}<18.5 \\
\text { NW } 18.5 \text { to } 24.9 \\
\text { OW } 25 \text { to } 29.9 \\
\text { Obese } \geq 30\end{array}$ & $\begin{array}{c}\text { Maternal age, maternal } \\
\text { race/ethnicity }\end{array}$ & $\begin{array}{l}\mathrm{CP} \\
\mathrm{CLP}\end{array}$ \\
\hline $\begin{array}{c}\text { Rankin et al. } \\
{[\underline{61]}}\end{array}$ & 2010 & $\begin{array}{l}\text { North of } \\
\text { England, } \\
\text { UK }\end{array}$ & $\begin{array}{l}\text { Cohort } \\
\text { study }\end{array}$ & $\begin{array}{c}\text { Jan } 2003 \\
\text { to } \\
\text { Dec } 2005\end{array}$ & Hospital records & $\begin{array}{c}\mathrm{UW}<18.5 \\
\text { NW } 18.5 \text { to } 24.9 \\
\text { OW } 25 \text { to } 29.9 \\
\text { Obese } \geq 30\end{array}$ & $\begin{array}{c}\text { Maternal age, maternal } \\
\text { ethnicity, pre- } \\
\text { gestational diabetes, } \\
\text { cigarette smoking } \\
\text { status, index of multiple } \\
\text { deprivation }\end{array}$ & $\begin{array}{l}\text { CL } \\
\text { CP } \\
\text { CLP }\end{array}$ \\
\hline
\end{tabular}

$\mathrm{NW}=$ normal weight (reference weight); $\mathrm{OW}=$ overweight; $\mathrm{UW}=$ underweight; $\mathrm{CL}=$ cleft lip; $\mathrm{CP}=$ cleft palate; $\mathrm{CLP}=\mathrm{cleft}$ lip with or without palate. 
Table 5. Description of cases and controls for case control studies

\begin{tabular}{|c|c|c|c|c|}
\hline \multirow{2}{*}{\multicolumn{2}{|c|}{ Characteristics }} & \multicolumn{2}{|r|}{ Study } & \multirow[b]{2}{*}{ Watkins et al. [됴] } \\
\hline & & Waller et al. [32] & Stott-Miller et al. [46] & \\
\hline \multirow{2}{*}{ Ethnicity/race } & $\begin{array}{l}\text { Cases No. } \\
\qquad(\%)\end{array}$ & \begin{tabular}{|} 
Non-Hispanic white $6230(60.8)$ \\
Black $1047(10.2)$ \\
Hispanic $2394(23.4)$ \\
Other $555(5.4)$ \\
Missing $23(0.2)$
\end{tabular} & $\begin{array}{c}\text { White } 1674(80) \\
\text { Black/African American } 51(2) \\
\text { American Indian/Alaska Native } 73 \text { (4) } \\
\text { Asian } 121(6) \\
\text { Hawaiian/Pacific Islander } 10(1) \\
\text { Hispanic/Latino } 167(8) \\
\text { Other 2 (0) }\end{array}$ & $\begin{array}{l}59 \% \text { white } \\
41 \% \text { others }\end{array}$ \\
\hline & $\begin{array}{l}\text { Controls No. } \\
(\%)\end{array}$ & $\begin{array}{c}\text { Non-Hispanic white } 2439(60) \\
\text { Black } 487(12) \\
\text { Hispanic } 952(22.8) \\
\text { Other } 203(5) \\
\text { Missing } 11(0.3)\end{array}$ & \begin{tabular}{|c|} 
White $13617(77)$ \\
Black/African American $722(4)$ \\
American Indian/Alaska Native $419(2)$ \\
Asian $1073(6)$ \\
Hawaiian/Pacific Islander $72(0)$ \\
Hispanic/Latino 1682 (10) \\
Other 6 (0)
\end{tabular} & $\begin{array}{l}55 \% \text { white } \\
45 \% \text { others }\end{array}$ \\
\hline \multirow[t]{2}{*}{$\begin{array}{l}\text { Recruitment } \\
\text { sources }\end{array}$} & Case & \begin{tabular}{|c|} 
National Birth Defects \\
Prevention Study (NBDPS) \\
population in 8 states: Arkansas, \\
Iowa, Massachusetts, New \\
Jersey, Georgia, California, \\
Texas, and New York \\
\end{tabular} & Birth Certificate in Washington state & $\begin{array}{c}\text { Metropolitan Atlanta } \\
\text { Congenital Defects Program }\end{array}$ \\
\hline & Control & \begin{tabular}{|c} 
Birth certificates of 8 states: \\
Arkansas, Iowa, Massachusetts, \\
New Jersey, Georgia, California, \\
Texas, and New York
\end{tabular} & Birth Certificate in Washington state & $\begin{array}{l}\text { Hospitals registered with the } \\
\text { Atlanta Birth Defects Risk } \\
\text { factor Surveillance study }\end{array}$ \\
\hline \multirow{2}{*}{ Inclusion criteria } & Case & \begin{tabular}{|c|} 
Live birth \\
Fetal death \\
Pregnancy termination \\
\end{tabular} & $\begin{array}{c}\text { Live birth with } \\
\text { (ICD-9 diagnostic codes): } \\
749 \text { (CP) or } 749.1 \text { (CL) or } 749.2 \text { (CLP) }\end{array}$ & $\begin{array}{c}\text { Live birth } \\
\text { Fetal death } \\
\text { Pregnancy termination }\end{array}$ \\
\hline & Control & $\begin{array}{c}\text { Live birth } \\
\text { (randomly selected without } \\
\text { malformations) }\end{array}$ & $\begin{array}{c}\text { Live birth } \\
\text { (random sample without diagnosis of } \\
\text { orofacial) }\end{array}$ & $\begin{array}{c}\text { Live birth } \\
\text { (stratified random sample } \\
\text { without malformations) }\end{array}$ \\
\hline \multirow[t]{2}{*}{ Exclusion criteria } & Case & $\begin{array}{l}\text { Chromosomal abnormalities, } \\
\text { diabetes }\end{array}$ & $\begin{array}{c}\text { Chromosomal abnormalities, } \\
\text { diabetes }\end{array}$ & $\begin{array}{c}\text { Chromosomal abnormalities, } \\
\text { diabetes }\end{array}$ \\
\hline & Control & Diabetes & Diabetes & Diabetes \\
\hline \multirow{2}{*}{$\begin{array}{c}\text { Response rate of } \\
\text { maternal interview } \\
\text { for weight and } \\
\text { height information }\end{array}$} & Case & $71.4 \%$ & N/A & $\mathrm{N} / \mathrm{R}$ \\
\hline & Control & $67.9 \%$ & N/A & $\mathrm{N} / \mathrm{R}$ \\
\hline
\end{tabular}

$\mathrm{N} / \mathrm{R}=$ not reported; $\mathrm{N} / \mathrm{A}=$ not applicable, $\mathrm{CL}=$ cleft lip; $\mathrm{CP}=$ cleft palate; $\mathrm{CLP}=$ cleft lip with or without palate.

Only one article had the sole aim of determining the relationship between pre-maternal obesity and orofacial cleft [46].

However, conducting a meta-analysis of observational studies has its drawbacks because individual studies may be quite dissimilar in the way they define the outcome or exposure, and thus a true relationship may not be observed [62]. Therefore, a detailed evaluation of the three included studies was done to assess their suitability to be pooled together for a meta-analysis. Below are descriptions of the three studies included in the meta-analysis.

1. Waller et al. [32] conducted a case control study with title "Pre-pregnancy Obesity as a Risk Factor for Structural Birth Defects". Eight states in the United States of America participated; Arkansas,
Iowa, Massachusetts, New Jersey, Georgia, New york, California and Texas. The study period was between October 1, 1997 and December 31, 2002. The cases were selected from the National Birth Defects Prevention Study (NBDPS) and had one or more congenital malformations (isolated + nonisolated). They were further divided cases into isolated (those with only one form of congenital malformation) and non-isolated (those with more than one congenital malformation) birth defects. These included live birth, fetal death and pregnancy termination. Those with chromosomal abnormalities were excluded. Controls were un-matched live-born infants without birth defects. They were randomly selected from the birth certificate registry or birth hospitals of participating states. 
Maternal interviews were conducted mainly by telephone no earlier than six weeks after the estimated date of delivery and no longer than two years after delivery. The response rate was $71.4 \%$ among case mothers and $67.9 \%$ among controls mothers.

Pre-maternal weight and height were self-reported by the mothers. This information was used in calculating the BMI. Mothers that had reported preexisting diabetes were excluded from the analysis.

They adjusted for maternal age, maternal ethnicity, educational level of mother, parity, smoking in the month prior to conception, and intake of vitamins containing folic acid in the month prior to conception. Only the adjusted odds ratio for CP and CLP was reported because the authors said that both the adjusted and the crude odds ratios were similar.

2. Watkins et al. [58] conducted a case control study with title "Maternal Obesity and Risk for Birth Defects". The study was conducted in a 5-county metropolitan Atlanta, USA between January 1993 and August 1997. The cases were ascertained using the population-based Metropolitan Atlanta Congenital Defects Program. It is an active surveillance system. The cases had one or more congenital malformations (isolated + non-isolated). These included live births, stillbirths and pregnancy terminations. Those with chromosomal abnormalities were excluded. Controls were those without birth defects and were randomly selected from the same Atlanta counties as the cases.

Maternal interview was conducted through the telephone, but the response rate was not reported. The mothers reported their pre-maternal weight and height but the time was not specified, and these were used to calculate their BMI. Mothers that had reported pre-existing diabetes before pregnancy were excluded from the analysis. The authors adjusted for maternal age, education, alcohol use, smoking, regular use of multivitamin 1 month before through third month of pregnancy and race but reported that the crude and adjusted odd ratio were similar, so they decided to report only the crude odds ratios.

3. Stott Miller et al. [46] conducted a case control study with title "Increased risk of orofacial clefts associated with maternal obesity: case-control study and Monte Carlo-based bias analysis". The primary aim of the study was to determine the risk of having offspring with orofacial cleft in pre-maternal obese women. The study was conducted in USA and cases were live-born singletons ascertained from the state birth certificate registry data and birth hospitalization discharge records in Washington. Cases were identified using the International Classification of Disease (ICD) codes. Both isolated and non-isolated cases were recruited. Those with chromosomal abnormalities were excluded. Controls were selected randomly from life births in Washington and did not have any birth defects. Controls were also frequency matched according to year of birth with the cases.

Pre-pregnancy weight and height were retrieved from the birth certificate. Height and weight in the birth certificates are usually self-reported by the mother. If there were missing information on height their drivers' license was checked. About $50 \%$ of both cases and controls had missing information on weight and height, so BMI was not calculated and were excluded from the analysis. The only common characteristics reported by the author of these women with missing information on height and weight was that they had less than 12 years of education.

Women with preexisting diabetes were excluded. In the analysis, they adjusted for maternal education, maternal age, maternal smoking during pregnancy and maternal race. They reported the adjusted odds ratios.

\section{Definition of orofacial cleft}

Watkins et al. [됴] and Waller et al. [32] both recruited orofacial cleft cases that were life birth, stillbirths and those that had pregnancy terminations. They also ascertained their cases from a specified registry of congenital malformations. For Stott-Miller et al. [46] study, only life births of orofacial clefts were included. These were identified from the birth register using the International Classification of Disease (ICD9 codes for Congenital anomalies):

- Cleft palate: 749 ;

- Cleft lip: 749.1;

- Cleft lip/palate: 749.2.

\section{Definition of overweight/obese}

The pre-maternal weight and height were selfreported through interviews in both Waller et al. [32] and Watkins et al. [58] studies. In Stott-Millers et al. [46] study, height and weight measurements were obtained from the birth certificates or driver's license. However, information of the height and weight on the birth register is also self-reported by the mother.

In all three studies, women with diabetes were identified and excluded because diabetes is regarded as a confounding variable. The authors from the three studies also classified the cases according to sub-groups CP and CLP because these subgroups are known to have different risk factors and should be analyzed differently. Watkins et al. [됴] did not report the adjusted odds ratio, but StottMiller et al. [46] and Waller et al. [32] did. Since all the adjusted odds ratios were not available, 
it was decided that only raw data from all the three studies was used for the meta-analysis to allow uniformity.

The three studies were quite similar it several ways. Then, it was decided that it was appropriate to conduct a meta-analysis.

Meta-analysis has the advantages of quantifying and summarizing the results of multiple studies. The power to detect the effect size by combining studies is another advantage of meta-analysis and the results can be easily conveyed and understood by those concerned [63].

\section{Relationship between obesity and CP/CLP}

The proportion of $\mathrm{CP}$ in the obese group ranged from $4.03 \%$ to $15.48 \%$ versus a range from $3.08 \%$ to $12.84 \%$ in the normal weight group. Stott-Miller et al. [46] and Waller et al. [32] did report a higher proportion of CP in the obese group when compared with the normal weight group. However, Watkins et al. [58] reported a lower proportion of $\mathrm{CP}$ in the obese group.

The proportion of CLP in the obese group ranged from $7.34 \%$ to $22.39 \%$ versus a range from $5.92 \%$ to $20.9 \%$ in the normal weight group. The results of all three studies revealed a higher proportion of CLP in the obese group women.

\section{Relationship between overweight and CP/CLP}

The proportion of $\mathrm{CP}$ in the overweight group ranged from $2.84 \%$ to $12.72 \%$ compared to a range of $1.28 \%$ to $9.4 \%$ in the normal weight group. Stott-Miller et al. [46] and Watkins et al. [58] did report a slightly higher proportion of cases in the normal weight, but Waller et al. [32] detected more proportion of cases in the overweight group.

The proportion of CLP in the overweight ranged from $7.16 \%$ to $20.04 \%$ while that of the normal weight ranged from $5.92 \%$ to $20.9 \%$. The results of two studies reported a higher proportion of CLP in the overweight group. Waller et al. [32] reported a slightly reduced value of $20.04 \%$ in the overweight group when compared to $20.9 \%$ in the normal weight group.

\section{Meta-analysis}

Table 6 shows the studies and subgroups that were intended to be used for the meta-analysis. However, it was only Waller et al. [32] that investigated the nonisolated cases as a single entity. Stott-Miller et al. [46] and Watkins et al. [됴] did not. So, "isolated and nonisolated" cases had to be investigated together.
Tables 7A and 8A shows the data for obese and overweight and the outcome of orofacial cleft reported that was used in the analysis.

The results of the meta-analysis with the forest plot are shown in Figures 2 - 5.

Mothers that had pre-maternal obesity were at increased odds of having offspring with CLP when compared with mothers of recommended BMI (OR, 1.16 ; $95 \% \mathrm{CI}, 1-1.34 ; \mathrm{P}=0.05)$ with an $\mathrm{I}^{2}$ of $0 \%$. Obese mothers were also at slightly increased odds of have offspring with $\mathrm{CP}(\mathrm{OR}, 1.14 ; 95 \% \mathrm{CI}, 0.95$ $1.37 ; \mathrm{P}=0.15)$ with an $\mathrm{I}^{2}$ of $0 \%$.

For mothers that were overweight prior to pregnancy, there was no increased odds of having offspring with CP (OR 0.89; 95\% CI, $0.75-1.06 ; \mathrm{P}=0.19$ ) with an $\mathrm{I}^{2}$ of $14 \%$, but there was a slightly increased odds of having offspring with CLP (OR 1.06; 95\% CI, 0.93 $1.21 ; \mathrm{P}=0.39$ ) with an $\mathrm{I}^{2}$ of $48 \%$.

Statistical significance was only obtain for the relationship between obesity and CLP.

The odds ratios were higher for the obese women in both CP and CLP when compared with the overweight group.

On visual inspection of funnel plots, there was no indication of publication bias except for the relationship between overweight and CLP. There was an indication of bias towards one small study in which there was a large effect size in favour of the overweight group.

Results from the studies that met the inclusion criteria but were not included in the meta-analysis are summarized in Tables 7B, 7C, 8B and 8C.

For Block et al. [무] and Marengo et al. [60] cross sectional studies, the obese group was further divided into three categories: class I obese (BMI 30 - 34.9), class II obese (35 - 39.9) and class III obese $(\geq 40)$.

Table 6. Outcomes reported by authors

\begin{tabular}{c|c|c|c}
\hline \multirow{2}{*}{ Outcome reported } & \multicolumn{3}{|c}{ Study } \\
\cline { 2 - 4 } & $\begin{array}{c}\text { Waller } \\
\text { et al. [32] }\end{array}$ & $\begin{array}{c}\text { Stott-Miller } \\
\text { et al. [46] }\end{array}$ & $\begin{array}{c}\text { Watkins } \\
\text { et al. [ㄷ] }\end{array}$ \\
\hline $\begin{array}{c}\text { Cleft palate } \\
\text { (isolated + non isolated) }\end{array}$ & + & + & + \\
\hline $\begin{array}{c}\text { Cleft lip/palate } \\
\text { (isolated + non isolated) }\end{array}$ & + & + & + \\
\hline $\begin{array}{c}\text { Cleft palate } \\
\text { (non isolated) }\end{array}$ & + & - & - \\
\hline $\begin{array}{c}\text { Cleft lip/palate } \\
\text { (non isolated) }\end{array}$ & + & - & - \\
\hline $\begin{array}{c}\text { Cleft palate } \\
\text { (isolated) }\end{array}$ & + & + & - \\
\hline $\begin{array}{c}\text { Cleft lip/palate } \\
\text { (isolated) }\end{array}$ & + & + & - \\
\hline \multicolumn{2}{c}{}
\end{tabular}


Table 7A. Relationship between maternal obesity and cleft palate (CP) / cleft lip with or without palate (CLP) for case control studies

\begin{tabular}{|c|c|c|c|c|c|}
\hline \multirow{2}{*}{ Study } & \multirow{2}{*}{ Controls } & \multicolumn{2}{|r|}{$\mathbf{C P}$} & \multicolumn{2}{|c|}{ CLP } \\
\hline & & Cases & AORs (95\% CI) & Cases & AORs (95\% CI) \\
\hline Waller et al. [32] & $\begin{array}{c}\text { Obese }=572 \\
\mathrm{NW}=2241 \\
\text { Total }=2813\end{array}$ & $\begin{array}{c}\text { Obese }=104 \\
\text { NW }=330 \\
\text { Total }=434\end{array}$ & $1.26(0.99-1.61)$ & $\begin{array}{c}\text { Obese }=165 \\
\mathrm{NW}=592 \\
\text { Total }=757\end{array}$ & $1.13(0.92-1.38)$ \\
\hline Stott-Miller et al. [느] & $\begin{array}{c}\text { Obese }=1452 \\
\mathrm{NW}=4829 \\
\text { Total }=6281\end{array}$ & $\begin{array}{c}\text { Obese }=61 \\
\mathrm{NW}=191 \\
\text { Total }=252\end{array}$ & $1.04(0.76-1.42)$ & $\begin{array}{c}\text { Obese }=115 \\
\text { NW }=304 \\
\text { Total }=419\end{array}$ & $1.25(0.99-1.59)$ \\
\hline Watkins et al. [58] & $\begin{array}{c}\text { Obese }=36 \\
\text { NW }=212 \\
\text { Total }=248\end{array}$ & $\begin{array}{c}\text { Obese }=2 \\
N W=22 \\
\text { Total }=24\end{array}$ & ${ }^{\mathrm{a}} 0.5(0.1-2.4)$ & $\begin{array}{c}\text { Obese }=4 \\
\text { NW }=21 \\
\text { Total }=25\end{array}$ & ${ }^{\mathrm{a}} 1.1(0.4-3.5)$ \\
\hline
\end{tabular}

${ }^{a} \mathrm{OR}$ is unadjusted. The adjusted OR was not reported.

Cases included both isolated and non-isolated orofacial cleft.

Excluded preexisting diabetes.

$\mathrm{NW}=$ normal weight (reference weight).

Table 7B. Relationship between maternal obesity and cleft palate (CP) / cleft lip with or without palate (CLP) for cross sectional studies

\begin{tabular}{l|c|c|c|c|c|c}
\hline \multirow{2}{*}{ Study } & \multicolumn{3}{|c|}{ CPAORs (95\% CI) } & \multicolumn{3}{c}{ CLP AORs (95\% CI) } \\
\cline { 2 - 7 } & Class I & Class II & Class III & Class I & Class II & Class III \\
\hline Block et al. [ $\underline{59}]$ & $1.27(0.98-1.63)$ & $1.67(1.21-2.3)$ & $0.97(0.59-1.62)$ & $1.21(0.98-1.49)$ & $1.29(0.96-1.74)$ & $1.30(0.9-1.89)$ \\
\hline Marengo et al. [무] & $1.46(1.16-1.83)$ & $1.33(0.94-1.83)$ & $1.49(0.98-2.17)$ & $1.13(0.93-1.36)$ & $1.12(0.84-1.46)$ & $1.55(1.14-2.07)$ \\
\hline
\end{tabular}

Table 7C. Relationship between maternal obesity and cleft palate (CP) and cleft lip with or without palate (CLP) for cohort study

\begin{tabular}{c|c|c}
\hline Study & CP AOR (95\% CI) & CLP AORs (95\% CI) \\
\hline Rankin et al. [61] & $0.87(0.18-4.24)$ & $1.48(0.46-4.76)$ \\
\hline
\end{tabular}

Table 8A. Relationship between maternal overweight and cleft palate (CP) / cleft lip with or without palate (CLP) of case control studies

\begin{tabular}{|c|c|c|c|c|c|}
\hline \multirow{2}{*}{ Study } & \multirow{2}{*}{ Control } & \multicolumn{2}{|r|}{$\mathbf{C P}$} & \multicolumn{2}{|r|}{ CLP } \\
\hline & & Cases & ${ }^{a}$ ORs $(95 \%$ CI) & Cases & ${ }^{\mathrm{a}}$ ORs (95\% CI) \\
\hline Waller et al. [32] & $\begin{array}{c}\mathrm{OW}=858 \\
\mathrm{NW}=2241 \\
\text { Total }=3099\end{array}$ & $\begin{array}{l}\mathrm{OW}=125 \\
\mathrm{NW}=330 \\
\text { Total }=455\end{array}$ & $1.03(0.82-1.28)$ & $\begin{array}{c}\mathrm{OW}=215 \\
\mathrm{NW}=592 \\
\text { Total }=807\end{array}$ & $0.97(0.81-1.15)$ \\
\hline Stott-Miller et al. [ㄷ] & $\begin{aligned} \mathrm{OW} & =1945 \\
\mathrm{NW} & =4829 \\
\text { Total } & =6774\end{aligned}$ & $\begin{array}{c}\mathrm{OW}=57 \\
\mathrm{NW}=191 \\
\text { Total }=248\end{array}$ & $0.84(0.66-1.08)$ & $\begin{array}{c}\mathrm{OW}=149 \\
\mathrm{NW}=304 \\
\text { Total }=453\end{array}$ & $1.27(1.06-1.53)$ \\
\hline Watkins et al. [묘] & $\begin{array}{c}\mathrm{OW}=55 \\
\mathrm{NW}=212 \\
\text { Total }=267\end{array}$ & $\begin{array}{c}\mathrm{OW}=5 \\
\mathrm{NW}=22 \\
\text { Total }=27\end{array}$ & ${ }^{\mathrm{a}} 0.9(0.3-2.4)$ & $\begin{array}{c}\mathrm{OW}=8 \\
\mathrm{NW}=21 \\
\text { Total }=29\end{array}$ & ${ }^{\mathrm{a}} 1.5(0.6-3.5)$ \\
\hline
\end{tabular}

${ }^{a} \mathrm{OR}$ is unadjusted. The Adjusted OR was not reported.

Cases included both isolated and non-isolated orofacial cleft.

Excluded preexisting diabetes.

$\mathrm{NW}=$ normal weight (reference weight); $\mathrm{OW}=$ overweight .

Table 8B. Relationship between maternal overweight and cleft palate (CP) / cleft lip with or without palate (CLP) for cross sectional studies

\begin{tabular}{|c|c|c|}
\hline Study & CP AORs (95\% CI) & CLP AORs $(95 \% \mathrm{CI})$ \\
\hline Block et al. [모] & $0.97(0.79-1.2)$ & $0.97(0.82-1.16)$ \\
\hline Marengo et al. [60] & $1.28(1.06-1.53)$ & $1.06(0.91-1.22)$ \\
\hline
\end{tabular}

Table 8C. Relationship between maternal overweight and cleft palate (CP) / cleft lip with or without palate (CLP) for cohort study

\begin{tabular}{c|c|c}
\hline Study & CP AORs (95\% CI) & CLP AORs (95\% CI) \\
\hline Rankin et al. [61] & $0.86(0.22-3.34)$ & $0.85(0.26-2.7)$ \\
\hline
\end{tabular}




\begin{tabular}{|c|c|c|c|c|c|c|c|c|c|}
\hline \multirow[b]{2}{*}{ Study or Subgroup } & \multicolumn{2}{|c|}{ case } & \multicolumn{2}{|c|}{ Control } & \multirow[b]{2}{*}{ Weight } & \multirow{2}{*}{$\begin{array}{c}\text { Odds Ratio } \\
\text { M-H, Fixed, } 95 \% \mathrm{Cl}\end{array}$} & \multirow{2}{*}{\multicolumn{3}{|c|}{$\begin{array}{c}\text { Odds Ratio } \\
\text { M-H, Fixed, } 95 \% \mathrm{Cl}\end{array}$}} \\
\hline & Events & Total & Events & Total & & & & & \\
\hline Waller et al. [32] & 165 & 757 & 572 & 2813 & $58.0 \%$ & $1.09[0.90,1.33]$ & & $F$ & \\
\hline Stott-Miller et al. [46] & 115 & 419 & 1452 & 6281 & $40.3 \%$ & $1.26[1.01,1.57]$ & & & \\
\hline Watkins et al. [58] & 4 & 25 & 36 & 248 & $1.7 \%$ & $1.12[0.36,3.46]$ & & & \\
\hline Total (95\% CI) & & 1201 & & 9342 & $100.0 \%$ & $1.16[1.00,1.34]$ & & $\checkmark$ & \\
\hline Total events & 284 & & 2060 & & & & & & \\
\hline $\begin{array}{l}\text { Heterogeneity. } \mathrm{Chi}^{2}= \\
\text { Test for overall effect: }\end{array}$ & $\begin{array}{l}0.88, \mathrm{df} \\
Z=1.99\end{array}$ & $\begin{array}{l}=2(P \\
(P=0\end{array}$ & $\begin{array}{l}=0.64 j ; \\
.051\end{array}$ & $1^{2}=0 \%$ & & & $\begin{array}{ll}0.01 & 0.1 \\
\text { Favours [experimental] }\end{array}$ & $\begin{array}{cc}1 & 10 \\
\text { Favours [control] }\end{array}$ & 100 \\
\hline
\end{tabular}

Figure 2. Forest plot of relationship between obese and CLP.

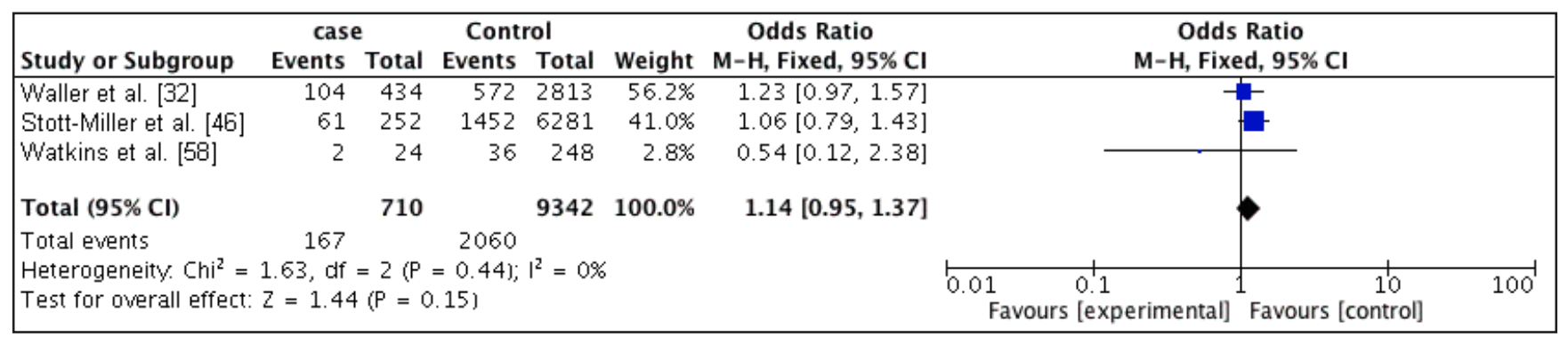

Figure 3. Forest plot of relationship between obese and CP.

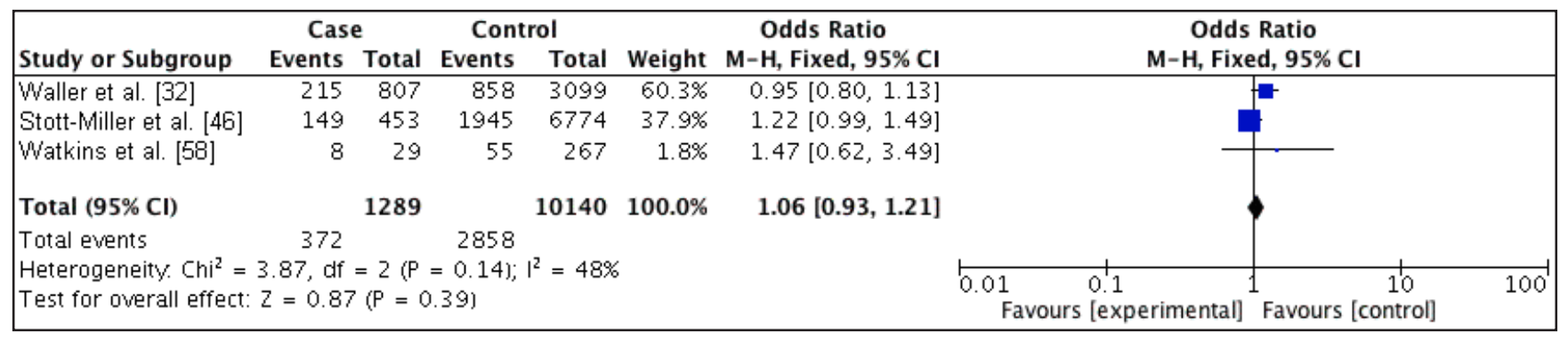

Figure 4. Forest plot of relationship between overweight and CLP.

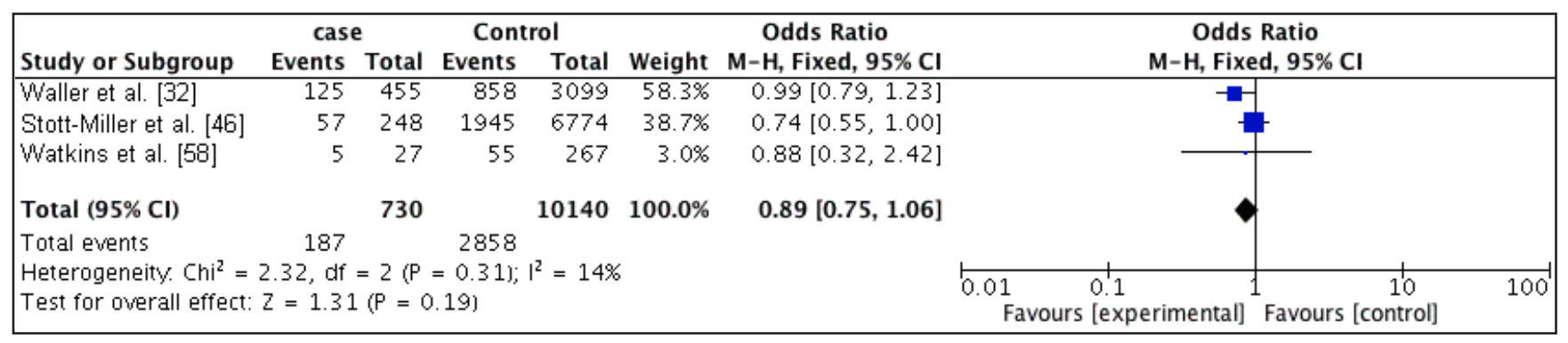

Figure 5. Forest plot of relationship between overweight and CP.

\section{Quality assessment}

The quality of the studies is summarized in Table 9A and 9B. Waller et al. [32] study was considered having high quality while Stott-Miller et al. [46] and Watkins et al. [두] were of moderate quality.

All studies addressed a clearly focused question and used an appropriate method in answering the research question. In the three studies, cases and controls were defined precisely and recruited from comparable populations. Waller et al. [32] and StottMiller et al. [46] had relatively large number of cases when compared with Watkins study. However, no power calculation was done in the three studies.

Waller et al. [32] reported the response rates of the maternal interview for both cases and controls but Watkins et al. [58] did not. Waller et al. [32] and Watkins et al. [58] did use subjective methods by selfreporting of maternal weight to measure the exposure, but this method has been previously validated and is a reliable way of estimating previous weight [64]. Stott-Miller et al. [46] did also use self-reporting of maternal weight and height, which is recorded in the birth certificate and on the driver's license. 
Table 9A. Quality assessment of case control and cross sectional studies

\begin{tabular}{|c|c|c|c|c|c|}
\hline \multirow{3}{*}{ Question } & \multicolumn{5}{|c|}{ Study } \\
\hline & \multicolumn{3}{|c|}{ Case control } & \multicolumn{2}{|c|}{ Cross sectional } \\
\hline & $\begin{array}{c}\text { Waller et al. } \\
{[\underline{32}]}\end{array}$ & Stott-Miller et al. & Watkins et al. & $\begin{array}{l}\text { Block et al. } \\
{[\underline{59}]}\end{array}$ & $\underset{[\underline{60}]}{\text { Marengo et al. }}$ \\
\hline 1."Did the study address a clearly focused issue?" & Yes & Yes & Yes & Yes & Yes \\
\hline $\begin{array}{l}\text { 2.'Did the authors use an appropriate method to } \\
\text { answer their question? }\end{array}$ & Yes & Yes & Yes & Yes & Yes \\
\hline 3."Were the cases recruited in a acceptable way?" & Yes & Yes & Yes & Yes & Yes \\
\hline $\begin{array}{l}\text { 4."Were the controls selected in an acceptable } \\
\text { way?" }\end{array}$ & Yes & Yes & $\begin{array}{c}\text { Can't tell } \\
\text { (response rate was } \\
\text { not reported) }\end{array}$ & N/A & N/A \\
\hline $\begin{array}{l}\text { 5."Was the exposure accurately measured to } \\
\text { minimize bias?" }\end{array}$ & Yes & Yes & Yes & Yes & Yes \\
\hline $\begin{array}{l}\text { 6a."What confounding factors have the authors } \\
\text { accounted for?" }\end{array}$ & $\begin{array}{l}\text { As shown in } \\
\text { Table } 4\end{array}$ & $\begin{array}{l}\text { As shown in } \\
\text { Table } 4\end{array}$ & $\begin{array}{l}\text { As shown in } \\
\text { Table } 4\end{array}$ & $\begin{array}{l}\text { As shown in } \\
\text { Table } 4\end{array}$ & $\begin{array}{l}\text { As show in } \\
\text { Table } 4\end{array}$ \\
\hline $\begin{array}{l}\text { 6b."Have the authors taken account of the potential } \\
\text { confounding factors?" }\end{array}$ & Yes & No & Yes & No & No \\
\hline 7."What are the results of this study?" & $\begin{array}{c}\text { As shown in } \\
\text { Tables 7A and } 8 \mathrm{~A}\end{array}$ & $\begin{array}{c}\text { As shown in } \\
\text { Tables 7A and 8A }\end{array}$ & $\begin{array}{c}\text { As shown in } \\
\text { Tables 7A and } 8 \mathrm{~A}\end{array}$ & \begin{tabular}{|c|} 
As shown in \\
Tables $7 \mathrm{~B}$ and $8 \mathrm{~B}$
\end{tabular} & $\begin{array}{c}\text { As shown in } \\
\text { Tables } 7 \mathrm{~B} \text { and } 8 \mathrm{~B}\end{array}$ \\
\hline 8."How precise is the estimate of risk?" & $\begin{array}{c}\text { As shown in } \\
\text { Tables 7A and } 8 \mathrm{~A}\end{array}$ & $\begin{array}{c}\text { As shown in } \\
\text { Tables 7A and 8A }\end{array}$ & $\begin{array}{c}\text { As shown in } \\
\text { Tables 7A and 8A }\end{array}$ & \begin{tabular}{|c|} 
As shown in \\
Tables $7 \mathrm{~B}$ and $8 \mathrm{~B}$
\end{tabular} & $\begin{array}{c}\text { As shown in } \\
\text { Tables } 7 \mathrm{~B} \text { and } 8 \mathrm{~B}\end{array}$ \\
\hline 9."Do you believe the result?" & Yes & \begin{tabular}{|c|} 
Yes \\
\end{tabular} & \begin{tabular}{|c|} 
Yes \\
\end{tabular} & \begin{tabular}{|c|} 
Yes \\
\end{tabular} & Yes \\
\hline $\begin{array}{l}\text { 10."Can the results be applied to the local } \\
\text { population?" }\end{array}$ & Yes & Yes & Yes & Yes & No \\
\hline $\begin{array}{l}\text { 11."Do the result of the study fit with other } \\
\text { available evidence?" }\end{array}$ & Yes & Yes & No & Yes & Yes \\
\hline
\end{tabular}

$\mathrm{N} / \mathrm{A}=$ not applicable

Table 9B. Quality assessment of cohort study

\begin{tabular}{l|c}
\hline \multicolumn{1}{c|}{ Question } & Study \\
\cline { 2 - 2 } & Rankin et al. [61] \\
\hline 1. "Did the study address a clearly focused issue?" & Yes \\
\hline 2. "Was the cohort recruited in an acceptable way?" & Yes \\
\hline 3. "Was the exposure accurately measured to minimise bias?" & Yes \\
\hline 4. "Was the outcome accurately measured to minimise bias?" & No \\
\hline 5a. "Have the authors identified all important confounding factors?" & No \\
\hline 5b. "Have they taken account of the confounding factors in the design and/or analysis?" & Yes \\
\hline 6a. "Was the follow up of subjects complete enough?" & Yes \\
\hline 6b. "Was the follow up of subjects long enough?" & As shown in Tables 7C and 8C \\
\hline 7. "What are the results of the study?" & As shown in Tables 7C and 8C \\
\hline 8. "How precise are the results?" & Yes \\
\hline 9. "Do you believe the results?" & Yes \\
\hline 10. "Wan the results be applied to the local population?' & Yes \\
\hline 11. "Do the results of this study fit with other available evidence?" & Obese women are at risk of orofacial cleft \\
\hline 12. "What are the implications of this study for practice?"
\end{tabular}

For about $50 \%$ of both cases and controls, there was no information on height and weight so BMI could not be calculated. The only common characteristics reported about these women were that they had less than 12 years of education. Waller et al. [60] and Watkins et al. [58] did take into account almost all risk factors but Stott-Miller et al. [46] did not. For example, they did not take into account folic acid use, which is known to be protective of orofacial cleft.
However, they did perform a Monte Carlo-based bias analysis, and the result suggests that these unadjusted risk factors did not modify the results significantly.

\section{DISCUSSION}

This is the first systematic review to investigate the association between orofacial cleft and prematernal obesity/overweight. 
The results of this meta-analysis suggest that prematernal obese women are at slightly increased odds of having offspring with CLP and CP when compared to women of pre-maternal normal weight. Statistical significance was obtained for the relationship between CLP and pre-maternal obesity. Pre-maternal overweight women were also at increased odds of having offspring with CLP but not for CP when compared with normal weight women. The odds ratios were higher in the obese group when compared with the overweight group.

The results of the two cross sectional studies were also in accordance with the result of the metaanalysis. An increased risk of CLP and CP was observed in the obese group when compared with women of normal weight. In the overweight group, there was an increased risk of CLP and CP in one of the studies but in the other study, this was not observed, however, the risk ratio of 0.97 were reported for both CLP and CP which is close to 1 . $\mathrm{BMI}$ in the obese group was further subdivided into three categories. The risk of having offspring with orofacial cleft increased in almost all strata of the obese group women as BMI increased. The risk ratios of either CLP or CP were higher for the obese women when compared with the overweight women.

The result of the cohort study suggest that prematernal obese women are at increased risk of having offspring with CLP when compared to women of prematernal normal weight but not for $\mathrm{CP}$ with risk ratio of 0.87. Pre-maternal overweight women were not at risk of having offspring with CLP or CP with risk ratios of 0.85 and 0.86 respectively. The risk ratios of either CLP or CP were also higher for the obese women when compared with the overweight women These patterns of higher odd ratios or risk ratios in obese women when compared with overweight women may suggest that there maybe a dose-response relationship. This implies that as the pre-maternal BMI of a woman increases above normal BMI, the greater the risk of having offspring with CLP and CP. These findings are consistent with the results of a meta-analysis conducted by Stothard et al. [48] and Molina-Solana et al. [49]. The aim of Stothard et al. [됴] review was to determine the association between pre-maternal obesity and congenital malformations in general, of which CP and CLP were included. The aim of Molina-Solana et al. [499] systematic review and meta-analysis was to identify the environmental risk factors for orofacial cleft. In both reviews, a wide range of databases was searched. Stothard et al. [48] searched MEDLINE, EMBASE, CINAHL and Scopus for articles (January 1966 through May 2008) for observational studies such as cross sectional studies, case control and cohort studies. Molina-Solana et al. [49] searched ISI proceedings from inception, EMBASE from 1974, PubMed from 1966, MEDLINE from 1966 till January 2011. They also searched Cochrane Controlled Trials Register for all types of studies. The search terms used in both studies were quite different. Stothard et al. [48] used terms such as "mother, weight and congenital malformations" while Molina-Solana et al. [49] used "cleft palate and cleft lip, obesity and mother" for their search. MolinaSolana et al. [49] search was narrower than that of Stothard et al. [48] because their study was focused on orofacial cleft rather than congenital malformations in general. Stothard et al. [48] identified and used three studies in the meta-analysis $[\underline{32}, \underline{44}, \underline{58}]$. Cedegren and Kallen [44] was a cross sectional study while the other two were case control studies. Molina-Solana et al. [49] identified and used two studies for the metaanalysis $[44,46]$. However, Cedegren and Kallen study [44] was identified but excluded from this review because BMI was not classified according to WHO recommendation. Cedegren and Kallen [44] classified BMI into obese (BMI > 29), overweight (BMI 26.1 to 29) and normal weight (BMI 19.8 to 26). Stothard et al. [48] reported an increased risk of pre-maternal obese/overweight women having offspring with $\mathrm{CP}$ and CLP when compared with pre-maternal normal weight women. Statistical significance was obtained in the obese women group and the risk of CP and CLP in their offspring, but statistical significance was not reported in the overweight group. The pooled odds ratio were: $1.23(95 \% \mathrm{CI}, 1.03-1.47 ; \mathrm{P}=02)$ for $\mathrm{CP}$ in the pre-maternal obese group and $1.20(95 \% \mathrm{CI}$, $1.03-1.40 ; \mathrm{P}=0.02)$ for CLP. In the pre-maternal overweight group, the pooled odds ratio of $1.02(0.86$ - 1.2) was reported for $C P$ and $1(0.87-1.15)$ for CLP. The odds ratio was higher for the obese women when compared to overweight women. Molina-Solana et al. [49] found an association between maternal obesity and orofacial cleft in general and reported an odds ratio of 1.26 (95\% CI, $1.07-1.5)$. They did not subdivide orofacial cleft into CP or CLP.

To ensure the best quality of this systematic review and meta-analysis, the protocol was registered with PROSPERO and no changes were made. The inclusion criteria were strictly adhered to. Only studies that categorized BMI according to WHO recommendation were included. Studies in which orofacial cleft was grouped as a single entity and not subdivided were excluded because it is known that both CP and CLP have different aetiology. Diabetes is considered a confounding variable when examining the association between obesity and orofacial cleft [56]. All studies included in this review did report 
excluding women with diabetes.

Another strength of this review is that not all the studies that met the inclusion criteria were included in the meta-analysis because they were of different study designs. Only the case control studies were included in the meta-analysis. The methods of cases and controls selection were examined and also the way the exposure were measured were assessed to make sure the studies were not so dissimilar before the metaanalysis was done. The heterogeneity results from the $\mathrm{I}^{2}$ statistics further confirmed that the studies were not substantially different. Two of the groups study, had an $\mathrm{I}^{2}$ statistics of $0 \%$. One of the main disadvantages of using case control design is the issue of unclear temporal association between the exposure and the outcome. However, this does not apply because prematernal overweight or pre-maternal obesity, which is the exposure, clearly occurred before the offspring with orofacial cleft is born which is the outcome in this case. For the cross sectional studies, pre maternal weight and height were collected before delivery so it is also clear that the exposure occurred before the outcome.

There are several methodological limitations of this review. Only electronic databases and Google scholar were searched for articles. A manual search of journals was not done. Thus this may have resulted in some relevant studies being excluded. There was also no attempt to access "gray literature" that could contain smaller null-result studies that were rejected for publication. Non-English publications were excluded so some relevant articles could have been missed. Although, funnel plots were used to assess the risk of publication bias and on visual inspection bias was not suspected. However, It is advised that, test for funnel plot asymmetry should only be used when the number of studies included for the meta-analysis are at least ten [65]. Higgins and Green [65] stated that this is because when there are few studies, there is no power to distinguish asymmetry from chance. Only three studies were included in this meta-analysis.

The validity of the results of a meta-analysis is inherent in the quality of the included studies. Maternal weight and height were self-reported through interviews by the mothers. In one of the studies, the interview was done about two years after delivery. This may be considered a relatively long period to recall weight accurately. However, self-reporting of previous weight has been observed to be accurate when the recall period is less than ten years [64].

Self-reported height and weight is subjective and unlikely to be precise. Women tend to underestimate their weight and over estimate their height. This would only be a problem if there is differential reporting based on case/control status, which is unlikely especially if weight and height values were obtained before delivery. However, for studies were weight and height measurement were self-reported by the mothers after delivery as stated in Waller et al. [32] study, the tendency of cases mother to report higher weight cannot be ruled out. They may think that the cause of orofacial cleft of their child could be due to them being obese/overweight and thus report a higher weight. This will result in an increased effect size. It is particularly important if the mothers were not blinded to the research question. It was not stated by Waller et al. [32] or Watkins et al. [58] if the mothers were blinded before the interview took place. The authors did not elaborate on the characteristic of the cases and controls status of missing BMI. StottMiller et al. [46] reported that $50 \%$ of information on BMI was missing and that those with missing BMI were more likely to have less than 12 years of education. Waller et al. [32] reported the response rate for maternal interview of cases and controls while Watkins et al. [58] did not. However, none of the authors compared the characteristics of missing data of cases with that of controls.

It is important to know this because a form of selection bias could be introduced if cases with missing BMI have different characteristics from controls.

Stott-Miller et al. [46] included only live birth of women, and it is known that obese women are at risk of fetal death [66]. Therefore, they may have differentially underestimated the true odds of birth defect amongst obese women and thus underestimated the risk.

This meta-analysis was done with only three studies. Although two of the studies were relatively large when compared with Watkins et al. [58] that had only eight cases of orofacial cleft. No power calculation was done in any of the studies prior to commencing the research. However, when power calculation using the nQuery Advisor Version 7.0 User's Guide [67] was done, a two group Chi-squared test with a 0.05 two-sided significance level will have $80 \%$ power to detect the difference between a control group proportion of obese/overweight mothers (0.3) and a case group proportion of 0.4 (odds ratio of 1.6) when the sample size in each group is 356 . None of the three studies have sufficient number of cases. The pooled study size of this meta-analysis was 284 for the relationship between obesity and CLP and 167 for the relationship between obesity and CP. The pooled study size for the overweight group was 372 for CLP and 187 for CP. This implies that this meta-analysis, did not have adequate sample 
size except for the relationship between overweight and CLP. It is therefore, important that adequate numbers of cases are identified to enable more precise measurement of the effect size.

There is a possibility of a missed diagnosis of CP. CL could be easily identified at birth because of the visible defect on the lip [68]. For CP, the diagnosis maybe made only after the child starts presenting with feeding difficulties [69]. Thus, the defect will not be recorded on the birth registry. So in studies that the cases were obtained from the birth registry and birth hospital discharge records, like that of StottMillers et al. [46] study, it is possible they missed some babies with CP. According to Craniofacial Anomalies Network (CRANE), in The UK 3.9\% of children born in 2011 with CP in England, Northern Ireland and Wales were undiagnosed at birth but were later diagnosed between one to six months after birth. However, forty cases of CP between 2006 and 2010 were diagnosed after six months of birth [70].

Another limitation was that five studies were conducted in the USA and one in UK and thus it may no be appropriate to generalize the results of the study to other populations. However, the study participants were from varied race and ethnicity but majority of them were White Americans.

Only raw data was used in the meta-analysis, and thus adjustments for the risk factor like maternal smoking, maternal race/ethnicity and maternal educational levels was not taken into account. However, the authors of all three studies included in the metaanalysis did report that the crude ORs were similar to the adjusted ORs. Although, it could have been possible that when all adjusted ORs were pooled, a difference could have been found and thus the results of the meta-analysis modified.

The major disadvantage with the cross sectional design in general is how the confounding variables and risk factors are addressed. Block et al. [59] and Marengo et al. [60] reported that information on these variables were not available on the registry so they would not adjust for all the factors they intended to adjust for. Information on intake of folic acid was not recorded in the registry.

Isolated and non-isolated CP and CLP cases are thought to have different risk factors and should be study differently. It was intended that these groups be analyse differently, but the unavailability of data was an hindrance. It was only Waller et al. [58] that analyzed non-isolated cases of CP and CLP separately from the isolated cases. So we had nothing to compare it with.

This review demonstrates the association between pre-maternal overweight and obesity and the risk of orofacial cleft in their offspring. The risk increases as BMI increases. Other congenital malformations like ventricular septal defect and patent ductus arteriosus also show a similar association [60]. Thus, the disability associated with obesity does to end with the mother. It is transferred to the offspring. These children continue to seek medical and dental care for a reasonably long period of their lives. They are also known to have reduced quality of life and their mortality rate is higher than those without orofacial cleft. If this is taken into consideration, the Disability Adjusted Life Years (DALY's), which is not just a measure of mortality, but also disabilities, lost to obesity and overweight will be much higher than reported. It is therefore, necessary to adopt strategy to reduce maternal overweight and obesity. Weight loss during pregnancy is not recommended, but weight loss before conception should be encouraged if the women are overweight or obese. Weight loss can be difficult to achieve, but women should be encouraged and informed that the more they are towards the recommended weight, the more likely they are to have offspring without certain kinds of congenital malformations like orofacial cleft.

The American College of Obstetricians and Gynecologist [71] recommends that if possible, overweight women and obese women should be counselled before conception on the risk factors associated with maternal obesity [71]. They also advocate that the type of risk should be identified and quantified when possible. Weight gain is expected during pregnancy. The Institute of Medicine (IOM) guidelines are 25 to 35 pounds (11.3 to $15.9 \mathrm{~kg}$ ) for normal weight women, 15 to 25 pounds (6.8 to $11.3 \mathrm{~kg}$ ) for overweight women and 15 pounds $(6.8$ $\mathrm{kg}$ ) for obese women. In the absence of medical contradiction, pregnant obese women are advised to engage in moderate exercise for about ten minutes each day.

Obesity is preventable, a healthy diet and adequate exercise usually results in being healthy and having a healthy weight. Women of childbearing age should be informed about the association between orofacial cleft and obesity. They should be encouraged to maintain a healthy weight, as weight loss while pregnant is not encouraged.

The World Health Organization has advocated for more research to be done on orofacial cleft [72]. The International Collaborative Research on Craniofacial Anomalies in collaboration with WHO was set up to establish a global network for the purpose of encouraging research in craniofacial anomalies. Four main areas of research were identified, which are; genetic basis of craniofacial 
anomalies, hereditary/environmental interactions, revention and optimal treatment of craniofacial anomalies. However, they observed that most research done on orofacial clefts have been in Latin America, USA, Europe and Asia. They also reported that researches are done independently which is not ideal and that an international standardization of the research protocol will enhance both the validity and consistency of the study. This is similar to what we observed that classification of BMI was not consistent, and orofacial cleft was reported as a single entity. Relevant studies had to be excluded from this systematic review because of these inconsistencies.

\section{CONCLUSIONS}

The results of this meta-analysis and previous studies suggest that obese women are at a slightly higher risk of having offspring with orofacial cleft when compared to normal weight women and even overweight.

Although an increased risk was observed, statistical significance was only obtained for the relationship between cleft lip/palate and pre-maternal obesity. Thus, it cannot be ruled out that other effect observed was not due to chance.

The reliability (repeatability or consistency) of the result of this meta analysis cannot be ascertained with just three studies. Also, the sample size of all the three studies pooled together was not sufficient except for the relationship between overweight and cleft lip/ palate.

Further research needs to be done to investigate the reason for the relationship between obesity and orofacial clefts because the reason for this association is unknown.

Due to the nature of the research question, only observational studies could reveal this link.
It is therefore, necessary that these studies be conducted properly and similarly. For example, consensus should be reached on how weight classification should be done, and all researchers should comply accordingly. Orofacial cleft should be divided into cleft lip/palate and cleft palate and analyzed separately.

Hospital records should contain as much information as possible bearing in mind that these data could be used for research purposes. There should be a checklist of all relevant information needed, and this should be completed properly. It can be easy to obtain weight and height measures at the first antenatal clinic. This would prevent the subjective selfreporting of weight and time-consuming interviews. If information is also available for all confounding variable, these factors will be adjusted for during analysis and a more reliable result will be obtained.

When identifying cases for the link between maternal obesity and orofacial cleft, it would be ideal to include stillbirths as well as pregnancy termination and not only live births because obese women are at risk of fetal death when compared with normal weight women.

Surveillance birth defect registry should be available worldwide. Since the incidence of orofacial cleft varies worldwide and some ethnic groups are more at risk than the others, it would be appropriate to have research done in different areas, and the results compared.

\section{ACKNOWLEDGMENTS AND DISCLOSURE STATEMENTS}

The authors declare no conflict of interest.

This manuscript is based on the thesis presented for the degree of Masters in Science, Global Health and Management, Division of Applied Health Sciences, University of Aberdeen.

\section{REFERENCES}

1. The problem of overweight and obesity. Part 1. Geneva, Switzerland: World Health Organization; 2000. [URL: http://whqlibdoc.who.int/trs/WHO_TRS_894_(part1).pdf]

2. Gallagher D, Visser M, Sepúlveda D, Pierson RN, Harris T, Heymsfield SB. How useful is body mass index for comparison of body fatness across age, sex, and ethnic groups? Am J Epidemiol. 1996 Feb 1;143(3):228-39. [Medline: 8561156] [doi: 10.1093/oxfordjournals.aje.a008733]

3. Romero-Corral A, Somers VK, Sierra-Johnson J, Thomas RJ, Collazo-Clavell ML, Korinek J, Allison TG, Batsis JA, Sert-Kuniyoshi FH, Lopez-Jimenez F. Accuracy of body mass index in diagnosing obesity in the adult general population. Int J Obes (Lond). 2008 Jun;32(6):959-66. [Medline: 18283284] [PMC free article: 2877506] [doi: 10.1038/ijo.2008.11]

4. Budewig K, Crawford F, Hamlet N, Hanlon P, Muirie J, Ogilvie D. Obesity in Scotland: why diets, doctors and denial won't work. Edinburgh: Public Health Institute for Scotland; 2004 Mar. [URL: http://www.ogilvie.fastmail.co.uk/ healthyfuture/obesity.html]

5. Obesity and overweight. Fact sheet No.311. Geneva, Switzerland: World Health Organization; 2015 Jan. [URL: $\underline{\text { http://www.who.int/mediacentre/factsheets/fs311/en/] }}$ 
6. Finucane MM, Stevens GA, Cowan MJ, Danaei G, Lin JK, Paciorek CJ, Singh GM, Gutierrez HR, Lu Y, Bahalim AN, Farzadfar F, Riley LM, Ezzati M; Global Burden of Metabolic Risk Factors of Chronic Diseases Collaborating Group (Body Mass Index). National, regional, and global trends in body-mass index since 1980: systematic analysis of health examination surveys and epidemiological studies with 960 country-years and $9 \cdot 1$ million participants. Lancet. 2011 Feb 12;377(9765):557-67. [Medline: 21295846] [doi: 10.1016/S0140-6736(10)62037-5]

7. Global status report on noncommunicable disease 2010. Geneva, Switzerland: World Health Organization; 2011 Apr. [URL: http://www.who.int/nmh/publications/ncd report full en.pdf]

8. Hebebrand J, Hinney A, Knoll N, Volckmar AL, Scherag A. Molecular genetic aspects of weight regulation. Deutsches Aerzteblatt International. 2013;110(19):338. [Medline: 23762205]

9. Hebebrand J, Hinney A. Environmental and genetic risk factors in obesity. Child Adolesc Psychiatr Clin N Am. 2009 Jan;18(1):83-94. [Medline: 19014859] [doi: 10.1016/j.chc.2008.07.006]

10. Jeffery RW, Baxter J, McGuire M, Linde J. Are fast food restaurants an environmental risk factor for obesity? Int J Behav Nutr Phys Act. 2006 Jan 25;3:2. [Medline: 16436207] [PMC free article: 1397859] [doi: 10.1186/1479-5868-3-35]

11. Fisher SC, Kim SY, Sharma AJ, Rochat R, Morrow B. Is obesity still increasing among pregnant women? Prepregnancy obesity trends in 20 states, 2003-2009. Prev Med. 2013 Jun;56(6):372-8. [Medline: 23454595] [doi: 10.1016/j.ypmed.2013.02.015]

12. Heslehurst N, Ells LJ, Simpson H, Batterham A, Wilkinson J, Summerbell CD. Trends in maternal obesity incidence rates, demographic predictors, and health inequalities in 36,821 women over a 15-year period. BJOG. 2007 Feb;114(2):187-94. [Medline: 17305899] [doi: 10.1111/j.1471-0528.2006.01180.x]

13. Health: Increasing obesity in sub-Sahara Africa threatens child survival 2012. IRIN: humanit news analys. [URL: http://www.irinnews.org/report/96075/health-increasing-obesity-in-sub-saharan-africa-threatens-child-survival]

14. Cedergren MI. Maternal morbid obesity and the risk of adverse pregnancy outcome. Obstet Gynecol. 2004 Feb;103(2): 219-24. [Medline: 14754687] [doi: 10.1097/01.AOG.0000107291.46159.00]

15. Mossey PA, Little J. Epidemiology of oral clefts: an international perspective. In: Wyszynski DF, editor. Cleft lip and palate: from origin to treatment. New York: Oxford University Press; 2002. p. 127-58.

16. Cleft lip and palate - diseases and conditions identified in children and youth with special health needs (CYSHN). Minnesota Department of Health. [URL: http://www.health.state.mn.us/divs/cfh/topic/diseasesconds/cleftlippalate.cfm]

17. Mitchell LE, Beaty TH, Lidral AC, Munger RG, Murray JC, Saal HM, Wyszynski DF; International Consortium for Oral Clefts Genetics. Guidelines for the design and analysis of studies on nonsyndromic cleft lip and cleft palate in humans: summary report from a Workshop of the International Consortium for Oral Clefts Genetics. Cleft Palate Craniofac J. 2002 Jan;39(1):93-100. [Medline: 11772175] [doi: 10.1597/1545-1569(2002)0392.0.CO;2]

18. Derijcke A, Eerens A, Carels C. The incidence of oral clefts: a review. Br J Oral Maxillofac Surg. 1996 Dec;34(6):488-94. [Medline: 8971440] [doi: 10.1016/S0266-4356(96)90242-9]

19. Moore KL, Persaud TVN, Torchia MG. The developing human: clinically oriented embryology with student consult. 9th ed. Philadelphia, PA: Saunders/Elsevier; 2013. p.182-91.

20. Murray JC. Gene/environment causes of cleft lip and/or palate. Clin Genet.2002 Apr;61(4):248-56. [Medline: 12030886] [doi: 10.1034/j.1399-0004.2002.610402.x]

21. Boulet SL, Grosse SD, Honein MA, Correa-Villaseñor A. Children with orofacial clefts: health-care use and costs among a privately insured population. Public Health Rep. 2009 May-Jun;124(3):447-53. [Medline: 19445422] [PMC free article: 2663882]

22. Schutte BC, Murray JC. The many faces and factors of orofacial clefts. Hum Mol Genet. 1999;8(10):1853-9. [Medline: 10469837] [doi: $10.1093 / \mathrm{hmg} / 8.10 .1853$ ]

23. Mossey PA, Little J, Munger RG, Dixon MJ, Shaw WC. Cleft lip and palate. Lancet. 2009 Nov 21;374(9703):1773-85. [Medline: 19747722] [doi: 10.1016/S0140-6736(09)60695-4]

24. IPDTOC Working Group. Prevalence at birth of cleft lip with or without cleft palate: data from the International Perinatal Database of Typical Oral Clefts (IPDTOC). Cleft Palate Craniofac J. 2011 Jan;48(1):66-81. [Medline: 20507242] [doi: 10.1597/09-217]

25. Dixon MJ, Marazita ML, Beaty TH, Murray JC. Cleft lip and palate: understanding genetic and environmental influences. Nat Rev Genet. 2011 Mar;12(3):167-78. [Medline: 21331089] [doi: 10.1038/nrg2933]

26. Genisca AE, Frías JL, Broussard CS, Honein MA, Lammer EJ, Moore CA, Shaw GM, Murray JC, Yang W, Rasmussen SA; National Birth Defects Prevention Study. Orofacial clefts in the National Birth Defects Prevention Study, 1997-2004. Am J Med Genet A. 2009 Jun;149A(6):1149-58. [Medline: 19441124] [PMC free article: 3111146$]$ [doi: 10.1002/ajmg.a.32854]

27. Lithovius RH, Ylikontiola LP, Harila V, Sándor GK. A descriptive epidemiology study of cleft lip and palate in Northern Finland. Acta Odontol Scand. 2014 Jul;72(5):372-5. [Medline: 24255959] [doi: 10.3109/00016357.2013.840737]

28. Jensen BL, Kreiborg S, Dahl E, Fogh-Andersen P. Cleft lip and palate in Denmark, 1976-1981: epidemiology, variability, and early somatic development. Cleft Palate J. 1988 Jul;25(3):258-69. [Medline: 3262457]

29. Review of Cleft Lip \& Palate Surgical Service in Scotland. National Services Division. 2006 May. [URL: http://www.nsd.scot.nhs.uk] 
30. Eppley BL, van Aalst JA, Robey A, Havlik RJ, Sadove AM. The spectrum of orofacial clefting. Plast Reconstr Surg. 2005 Jun;115(7):101e-114e. Review. [Medline: 15923821] [doi: 10.1097/01.PRS.0000164494.45986.91]

31. Stanier P, Moore GE. Genetics of cleft lip and palate: syndromic genes contribute to the incidence of non-syndromic clefts. Hum Mol Genet. 2004 Apr 1;13 Spec No 1:R73-81. [Medline: 14722155]

32. Waller DK, Shaw GM, Rasmussen SA, Hobbs CA, Canfield MA, Siega-Riz AM, Gallaway MS, Correa A; National Birth Defects Prevention Study. Prepregnancy obesity as a risk factor for structural birth defects. Arch Pediatr Adolesc Med. 2007 Aug;161(8):745-50. [Medline: 17679655] [doi: 10.1001/archpedi.161.8.745]

33. Blomberg MI, Källén B. Maternal obesity and morbid obesity: the risk for birth defects in the offspring. Birth Defects Res A Clin Mol Teratol. 2010 Jan;88(1):35-40. [Medline: 19711433] [doi: 10.1002/bdra.20620]

34. Correa A, Gilboa SM, Besser LM, Botto LD, Moore CA, Hobbs CA, Cleves MA, Riehle-Colarusso TJ, Waller DK, Reece EA. Diabetes mellitus and birth defects. Am J Obstet Gynecol. 2008 Sep;199(3):237.e1-9. [Medline: 18674752] [doi: 10.1016/j.ajog.2008.06.028]

35. Mokdad AH, Ford ES, Bowman BA, Dietz WH, Vinicor F, Bales VS, Marks JS. Prevalence of obesity, diabetes, and obesityrelated health risk factors, 2001. JAMA. 2003 Jan 1;289(1):76-9. [Medline: 12503980] [doi: 10.1001/jama.289.1.76]

36. Becerra JE, Khoury MJ, Cordero JF, Erickson JD. Diabetes mellitus during pregnancy and the risks for specific birth defects: a population-based case-control study. Pediatrics. 1990 Jan;85(1):1-9. [Medline: 2404255]

37. Parker SE, Werler MM, Shaw GM, Anderka M, Yazdy MM; National Birth Defects Prevention Study. Dietary glycemic index and the risk of birth defects. Am J Epidemiol. 2012 Dec 15;176(12):1110-20. [Medline: 23171874] [PMC free article: 3571231] [doi: 10.1093/aje/kws201]

38. Kissebah AH, Freedman DS, Peiris AN. Health risks of obesity. Med Clin North Am. 1989 Jan;73(1):111-38. [Medline: 2643000]

39. Catalano PM. Management of obesity in pregnancy. Obstet Gynecol. 2007 Feb;109(2 Pt 1):419-33. [Medline: 17267845] [doi: 10.1097/01.AOG.0000253311.44696.85]

40. Wilcox AJ, Lie RT, Solvoll K, Taylor J, McConnaughey DR, Abyholm F, Vindenes H, Vollset SE, Drevon CA. Folic acid supplements and risk of facial clefts: national population based case-control study. BMJ. 2007 Mar 3;334(7591):464. [Medline: 17259187] [PMC free article: 1808175] [doi: 10.1136/bmj.39079.618287.0B]

41. van Rooij IA, Ocké MC, Straatman H, Zielhuis GA, Merkus HM, Steegers-Theunissen RP. Periconceptional folate intake by supplement and food reduces the risk of nonsyndromic cleft lip with or without cleft palate. Prev Med. 2004 Oct;39(4):689-94. [Medline: 15351534] [doi: 10.1016/j.ypmed.2004.02.036]

42. Bufalino A, Ribeiro Paranaíba LM, Nascimento de Aquino S, Martelli-Júnior H, Oliveira Swerts MS, Coletta RD. Maternal polymorphisms in folic acid metabolic genes are associated with nonsyndromic cleft lip and/or palate in the Brazilian population. Birth Defects Res A Clin Mol Teratol. 2010 Nov;88(11):980-6. [Medline: 20890936] [doi: 10.1002/bdra.20732]

43. Romitti PA, Sun L, Honein MA, Reefhuis J, Correa A, Rasmussen SA. Maternal periconceptional alcohol consumption and risk of orofacial clefts. Am J Epidemiol. 2007 Oct 1;166(7):775-85. [Medline: 17609516] [doi: 10.1093/aje/kwm146]

44. Cedergren M, Källén B. Maternal obesity and the risk for orofacial clefts in the offspring. Cleft Palate Craniofac J. 2005 Jul;42(4):367-71. [Medline: 16001917] [doi: 10.1597/04-012.1]

45. Moore LL, Singer MR, Bradlee ML, Rothman KJ, Milunsky A. A prospective study of the risk of congenital defects associated with maternal obesity and diabetes mellitus. Epidemiology. 2000 Nov;11(6):689-94. [Medline: 11055631] [doi: 10.1097/00001648-200011000-00013]

46. Stott-Miller M, Heike CL, Kratz M, Starr JR. Increased risk of orofacial clefts associated with maternal obesity: case-control study and Monte Carlo-based bias analysis. Paediatr Perinat Epidemiol. 2010 Sep;24(5):502-12. [Medline: 20670231] [PMC free article: 2965650] [doi: 10.1111/j.1365-3016.2010.01142.x]

47. Shaw GM, Todoroff K, Schaffer DM, Selvin S. Maternal height and prepregnancy body mass index as risk factors for selected congenital anomalies. Paediatr Perinat Epidemiol. 2000 Jul;14(3):234-9. [Medline: 10949215] [doi: 10.1046/j.1365-3016.2000.00274.x]

48. Stothard KJ, Tennant PW, Bell R, Rankin J. Maternal overweight and obesity and the risk of congenital anomalies: a systematic review and meta-analysis. JAMA. 2009 Feb 11;301(6):636-50. [Medline: 19211471] [doi: 10.1001/jama.2009.113]

49. Molina-Solana R, Yáñez-Vico RM, Iglesias-Linares A, Mendoza-Mendoza A, Solano-Reina E. Current concepts on the effect of environmental factors on cleft lip and palate. Int J Oral Maxillofac Surg. 2013 Feb;42(2):177-84. [Medline: 23228693] [doi: 10.1016/j.ijom.2012.10.008]

50. Stroup DF, Berlin JA, Morton SC, Olkin I, Williamson GD, Rennie D, Moher D, Becker BJ, Sipe TA, Thacker SB. Meta-analysis of observational studies in epidemiology: a proposal for reporting. Meta-analysis Of Observational Studies in Epidemiology (MOOSE) group. JAMA. 2000 Apr 19;283(15):2008-12. [Medline: 10789670] [doi: 10.1001/jama.283.15.2008]

51. Critical Appraisal Skills Programme: making sense of evidence. 11 questions to help you make sense of a case control study [Internet]. Oxford Public Health Resource Unit. 2004:1-4. [URL: http://w3.unisa.edu.au/cahe/resources/CAT/CATS/CASP_Case_control_Tool.pdf] 
52. Critical Appraisal Skills Programme: making sense of evidence. 12 questions to help you make sense of a cohort study. Oxford Public Health Resource Unit. 2004:1-4. [URL: http:/calder.med.miami.edu/portals/ebmfiles/UM\%20CASP\%20 Cohort $\% 20$ Assessment $\% 20$ Tool.pdf]

53. Review Manager (RevMan) [Computer program]. Version 5.2. Copenhagen: The Nordic Cochrane Centre, The Cochrane Collaboration, 2012. [URL: http://tech.cochrane.org/Revman]

54. Mutsaerts MAQ, Tromp L, Scholtens S, Kerstjens-Frederikse WS, Hoek A, De Walle HEK. Maternal obesity increases risk of congenital anomalies: a population-based study. In: human reproduction. England: Oxford univ press. 2013;28(1). p. i356-59. [URL: http://humrep.oxfordjournals.org/content/28/suppl_1/i356.full]

55. Oddy WH, De Klerk NH, Miller M, Payne J, Bower C. Association of maternal pre-pregnancy weight with birth defects: evidence from a case-control study in Western Australia. Aust N Z J Obstet Gynaecol. 2009 Feb;49(1):11-5. [Medline: 19281573] [doi: 10.1111/j.1479-828X.2008.00934.x]

56. García-Patterson A, Erdozain L, Ginovart G, Adelantado JM, Cubero JM, Gallo G, de Leiva A, Corcoy R. In human gestational diabetes mellitus congenital malformations are related to pre-pregnancy body mass index and to severity of diabetes. Diabetologia. 2004 Mar;47(3):509-14. [Medline: 14770278] [doi: 10.1007/s00125-004-1337-3]

57. Villamor E, Sparén P, Cnattingius S. Risk of oral clefts in relation to prepregnancy weight change and interpregnancy interval. Am J Epidemiol. 2008 Jun 1;167(11):1305-11. [Medline: 18375499] [doi: 10.1093/aje/kwn065]

58. Watkins ML, Rasmussen SA, Honein MA, Botto LD, Moore CA. Maternal obesity and risk for birth defects. Pediatrics. 2003 May;111(5 Pt 2):1152-8. [Medline: 12728129]

59. Block SR, Watkins SM, Salemi JL, Rutkowski R, Tanner JP, Correia JA, Kirby RS. Maternal pre-pregnancy body mass index and risk of selected birth defects: evidence of a dose-response relationship. Paediatr Perinat Epidemiol. 2013 Nov;27(6):521-31. [Medline: 24117964] [doi: 10.1111/ppe.12084]

60. Marengo L, Farag NH, Canfield M. Body mass index and birth defects: Texas, 2005-2008. Matern Child Health J. 2013 Dec;17(10):1898-907. [Medline: 23371247] [doi: 10.1007/s10995-012-1214-5]

61. Rankin J, Tennant PW, Stothard KJ, Bythell M, Summerbell CD, Bell R. Maternal body mass index and congenital anomaly risk: a cohort study. Int J Obes (Lond). 2010 Sep;34(9):1371-80. Erratum in: Int J Obes (Lond). 2010 Sep;34(9):1449. [Medline: 20368710] [doi: 10.1038/ijo.2010.66]

62. Simunovic N, Sprague S, Bhandari M. Methodological issues in systematic reviews and meta-analyses of observational studies in orthopaedic research. J Bone Joint Surg Am. 2009 May;91 Suppl 3:87-94. [Medline: 19411505] [PMC free article: 2698793] [doi: 10.2106/JBJS.H.01576]

63. Walker E, Hernandez AV, Kattan MW. Meta-analysis: Its strengths and limitations. Cleve Clin J Med. 2008 Jun;75(6): 431-9. [Medline: 18595551] [doi: 10.3949/ccjm.75.6.431]

64. Perry GS, Byers TE, Mokdad AH, Serdula MK, Williamson DF. The validity of self-reports of past body weights by U.S. adults. Epidemiology. 1995 Jan;6(1):61-6. [Medline: 7888448] [doi: 10.1097/00001648-199501000-00012]

65. Higgins JPT, Green S. Cochrane handbook for systematic reviews of interventions (version 5.0.2). [updated 2009 Sept]. The Cochrane Collaboration; 2009. [URL: http://handbook.cochrane.org/index.htm]

66. Thompson DR, Clark CL, Wood B, Zeni MB. Maternal obesity and risk of infant death based on Florida birth records for 2004. Public Health Rep. 2008 Jul-Aug;123(4):487-93. [Medline: 18763411] [PMC free article: 2430645]

67. Elashoff, JD. nQuery version 7.0 advisor user's guide. Los Angeles, CA, USA; 2007. [URL: http://statistical-solutionssoftware.com/wp-content/uploads/nQ70 version2 manual.pdf]

68. Mackeprang M, Hay S, Lunde AS. Completeness and accuracy of reporting of malformations on birth certificates. HSMHA Health Rep. 1972 Jan;87(1):43-9. [Medline: 5019168] [PMC free article: 1616116] [doi: 10.2307/4594425]

69. Gosain AK, Conley SF, Marks S, Larson DL. Submucous cleft palate: diagnostic methods and outcomes of surgical treatment. Plast Reconstr Surg. 1996 Jun;97(7):1497-509. [Medline: 8643740] [doi: 10.1097/00006534-199606000-00032]

70. On behalf of the Cleft Development Group. Annual Report on Cleft Lip and/or Palate 2014. Crane Database. [URL: https://www.crane-database.org.uk/publications/]

71. American College of Obstetricians and Gynecologists. Guidelines for women's health care. Amer Colleg of Obstetricians \& Gynecolog Wom Health Care Physic. 2002. [URL: http://www.acog.org/]

72. Global strategies to reduce the health-care burden of craniofacial anomalies: report of WHO Meetings on International Collaborative Research on Craniofacial Anomalies. Geneva, Switzerland: World Health Organization; 2002 Nov. [URL: http://apps.who.int/iris/handle/10665/42594] 


\section{To cite this article:}

Izedonmwen OM, Cunningham C, Macfarlane TV. What is the Risk of Having Offspring with Cleft Lip/Palate in PreMaternal Obese/Overweight Women When Compared to Pre-Maternal Normal Weight Women? A Systematic Review and Meta-Analysis.

J Oral Maxillofac Res 2015;6(1):e1

URL: http://www.ejomr.org/JOMR/archives/2015/1/e1/v6n1e1.pdf

doi: $\underline{10.5037 / \text { jomr.2015.6101 }}$

Copyright (C) Izedonmwen OM, Cunningham C, Macfarlane TV. Published in the JOURNAL OF ORAL \& MAXILLOFACIAL RESEARCH (http://www.ejomr.org), 31 March 2015.

This is an open-access article, first published in the JOURNAL OF ORAL \& MAXILLOFACIAL RESEARCH, distributed under the terms of the Creative Commons Attribution-Noncommercial-No Derivative Works 3.0 Unported License, which permits unrestricted non-commercial use, distribution, and reproduction in any medium, provided the original work and is properly cited. The copyright, license information and link to the original publication on (http://www.ejomr.org) must be included. 
Appendix 1. Search strategy for MEDLINE

Database: Ovid MEDLINE(R) $<1946$ to July week 1, 2014>

Search strategy

1. body weight/(162827)

2. Overweight/(12131)

3. over weight.tw. (300)

4. overweight.tw. (35166)

5. obes\$.tw. (165859)

6. Mothers/(26502)

7. exp Pregnant Women/(5570)

8. gravid\$.tw. (9511)

9. expectan\$.tw. (28521)

10. mother\$.tw. (144830)

11. pregnan\$.tw. (351962)

12. pregnan\$ wom?n.tw. (59935)

13. maternal.tw. (160395)

14. 1 or 2 or 3 or 4 or 5 (321037)

15.6 or 7 or 8 or 9 or 10 or 11 or 12 or $13(559729)$

16. 14 and 15 (21185)

17. ((obes\$ or overweight or over weight) adj4 pregnan\$).tw. (1804)

18. 16 or $17(21185)$

19. exp Child/(1549368)

20. Infant/ (636934)

21. child\$.tw. (942928)

22. infant\$.tw. (292921)

23. bab\$.tw. (69643)

24. off spring\$.tw. (183)

25.19 or 20 or 21 or 22 or 23 or 24 (2113639)

26. cleft lip/or cleft palate/(18890)

27. cleft lip palate.tw. (710)

28. (cleft lip adj5 palate).tw. (7000)

29. cleft palate.tw. (8608)

30. cleft lip.tw. (8691)

31. cheiloschisis.tw. (23)

32. hare lip.tw. (92)

33. palatoschisis.tw. (84)

34. orofacial cleft.tw. (170)

35. Congenital Abnormalities/(29902)

36. congenital abnor\$.tw. (5168)

37. congenital malforma\$.tw. (10540)

38.26 or 27 or 28 or 29 or 30 or 31 or 32 or 33 or 34 or 35 or 36 or 37 (62738)

39. 18 and 25 and 38 (146)

40. limit 39 to (english language and humans and $\mathrm{yr}=$ "1980 - current") (106) 